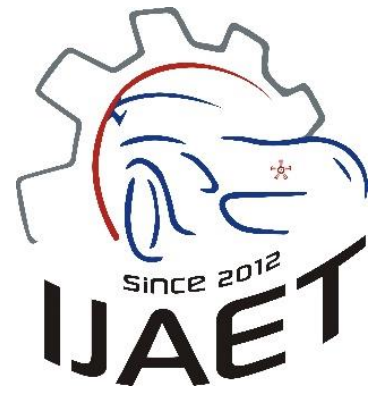

e-ISSN: 2146 - 9067

International Journal of Automotive

Engineering and Technologies

journal homepage: http://ijaet.academicpaper.org

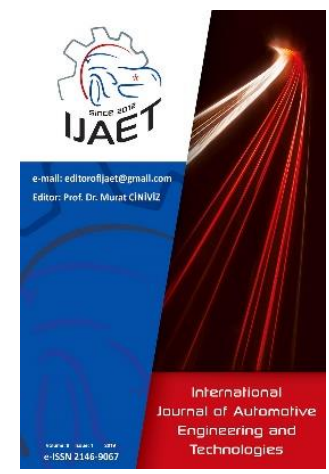

Review Article

\title{
Influence of swirl, tumble and squish flows on combustion characteristics and emissions in internal combustion engine- review
}

\section{Mahmut KAPLAN}

Amasya University Technology Faculty, Mechanical Engineering Department

\section{ARTICLE INFO}

* Corresponding author mahmut.kaplan@amasya.edu.tr

Received: April 26, 2019

Accepted: July 10, 2019

Published by Editorial Board Members of IJAET

(C) This article is distributed by Turk Journal Park System under the CC 4.0 terms and conditions.

\begin{abstract}
This study gives an overview of available literature on flow patterns such as swirl, tumble and squish in internal combustion engines and their impacts of turbulence enhancement, combustion efficiency and emission reduction. Characteristics of in-cylinder flows are summarized. Different design approaches to generate these flows such as directed ports, helical ports, valve shrouding and masking, modifying piston surface, flow blockages and vanes are described. How turbulence produced by swirl, tumble and squish flows are discussed. Effects of the organized flows on combustion parameters and exhaust emission are outlined. This review reveals that the recent investigations on the swirl, tumble and squish flows are generally related to improving in-cylinder turbulence. Thus, more experimental and numerical studies including the impacts of this organized flows on turbulence production, combustion behavior and pollutant formation inside the cylinder are needed.

Keywords: Internal combustion engines, swirl, tumble and squish flows, turbulent enhancement, combustion efficiency, emission
\end{abstract}

\section{Introduction}

Internal combustion (IC) engines are generally classified by spark ignition (SI) and compression ignition (CI) engines which generate work by burning gasoline and diesel fuel respectively. Both engines produce air pollution emissions such as carbon monoxide (CO), hydrocarbons ( $\mathrm{HC})$, oxides of nitrogen $\left(\mathrm{NO}_{\mathrm{x}}\right)$, sulfur dioxide $\left(\mathrm{SO}_{2}\right)$ and solid carbon particles which are responsible for environmental pollution and the greenhouse effects of the atmosphere. One important factor of controlling the combustion process and exhaust emission is increasing pre-combustion turbulence level by in-cylinder gas motion. The flow behavior in the IC engine is very complex. That is unsteady due to the reciprocating piston motion, turbulence and three-dimensionality. In turbulent flows, the diffusivity of turbulence is greater than molecular diffusion and it causes rapid mixing and augmenting rates of mass, heat and momentum transfer.

In the cylinder of a combustion engine, three common organized flows such as swirl, tumble and squish are generated by modifying intake ports, valves, cylinder head, piston surface and placing flow blockages, vanes in the intake ports. Swirl and tumble are both rotational flows and their rotation axes are parallel to the piston motion and perpendicular to the axis of the cylinder respectively. On the other hand, squish 
is a radial flow taking places at the end of the compression stroke towards the center-line of the cylinder. As the piston reaches Top Dead Center (TDC), the squish flow produces a secondary flow called tumble, where rotation occurs near a circumferential axis close to the outer edge of the piston cavity. At the end of the compression stroke, this large scale of organized flows breaks down into small scale eddies and turbulence level is enhanced. Therefore, more homogeneous air-fuel mixture is obtained before ignition. This provides increase of combustion efficiency, fuel economy and reduction of exhaust emissions resulting from high cylinder temperature, incomplete combustion and combustion instability which is especially an important problem for lean burning engines.

Various experimental methods are used to measure in-cylinder flow characteristics such as paddle wheel, hot wire anemometer (HWA), laser Doppler velocimetry (LDV), particle image velocimetry (PIV), particle tracking velocimetry (PTV) and molecular tagging velocimetry (MTV). Both HWA and LDA methods provide velocity and turbulence data at only selected points. As the velocity fields are complex, unsteady and display cyclic variations, whole field techniques such as PTV and PIV which have been preferred by many researchers. However, MTV is superior to other nonintrusive measurement methods, since flow is seeded with phosphorescent molecules that always follow the flow. Although significant progress has been made in the experimental measurement techniques, accessing in-cylinder processes in real engines are often impossible without greatly modifying the engine. Also, the uncertainty of measurements and the high cost of experimental set-up restrict the diagnostics of engine flow characteristics. Therefore, besides these experimental methods, to model incylinder flow accurately, the commercial CFD codes such as KIVA, STAR-CD, VECTIS, CFX, and ANSYS FLUENT have been developed during the last two decades. In these methods, the Navier-Stokes equations can be solved to obtain detailed description of the mean velocity and turbulence velocity field expense of calculation times and high computer memory requirement. In recent years, these drawbacks are significantly solved by development in power and speed of modern computers.

The theoretical and experimental studies in the available literature are summarized according to the basic data of these subjects such as bore, stroke and speed of the engine, type and generation of in-cylinder flow, and effect of combustion parameters and emission in the Table 1.

Aim of this study is to provide a comprehensive knowledge about swirl, tumble and squish flows, combustion efficiency and exhaust emission using available experimental and numerical studies. In the first section, generation and characteristics of swirl, tumble and squish flows are described. In the second section, turbulence enhancement methods related to swirl, tumble and squish flows are introduced. Finally, last section deals with influence of turbulence amplification on combustion efficiency and residual pollutant in IC engines.

\section{In Cylinder Flow of Internal Combustion Engines}

In this section, some dimensionless parameters related to swirl, tumble and squish flows are explained and generation of these flows is described by available experimental and numerical studies.

\subsection{Characteristics of swirl, tumble and squish flows}

Swirl and tumble are organized flow patterns with air or mixture of fuel and air rotating around the axes parallel to the cylinder motion and perpendicular to the axis of the piston motion, respectively, as shown in Fig. 1. The squish flow also produces tumble flow when the piston reaches Top Dead Center (TDC) as shown in Fig. 1.
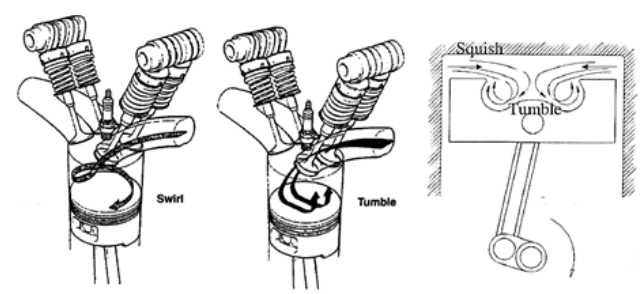

Fig. 1. Swirl, tumble and squish flows [1,2]

Swirl can be modeled as solid body rotation with conserved angular momentum. In order to quantify swirl motion within the cylinder, a dimensionless parameter known as the swirl ratio is used. It is expressed in two different ways [2]: 
Table 1 Summary of influence of in-cylinder flow on combustion efficiency and emission for internal combustion engine in chronological order with engine parameters

\begin{tabular}{|c|c|c|c|c|c|c|c|c|c|c|c|}
\hline Researchers & Year & Ignition & $\begin{array}{c}\text { Bore } x \text { stroke } \\
\quad(\mathbf{m m})\end{array}$ & Speed (rpm) & In cylinder flow & $\begin{array}{l}\text { Generation of } \\
\text { swirl, tumble } \\
\text { and squish }\end{array}$ & $\begin{array}{c}\text { Flow } \\
\text { measurement } \\
\text { techniques }\end{array}$ & $\begin{array}{c}\begin{array}{c}\text { Numerical and/or } \\
\text { experimental } \\
\text { methods }\end{array} \\
\end{array}$ & SR and/or TR & $\begin{array}{l}\text { Effect of combustion } \\
\text { characteristics }\end{array}$ & $\begin{array}{c}\text { Effect of } \\
\text { exhaust } \\
\text { emissions }\end{array}$ \\
\hline $\begin{array}{c}\text { Arcoumanis et al. } \\
{[30]}\end{array}$ & 1981 & - & $75 \times 94$ & 200 & swirl & $\begin{array}{l}\text { swirl vane, piston } \\
\text { bowl } \\
\end{array}$ & LDV & experimental & $\mathrm{SR}=1.2$ & - & - \\
\hline Pettiffer [6] & 1982 & $\mathrm{CI}$ & $120.65 \times 139.7$ & 2400 & swirl & $\begin{array}{l}\text { directed and } \\
\text { helical ports }\end{array}$ & LDV & experimental & $\mathrm{SR}=6-7.9$ & - & - \\
\hline $\begin{array}{c}\text { Liou and } \\
\text { Santavica [31] }\end{array}$ & 1983 & - & $82.6 \times 114.3$ & $1200,1800,2400$ & swirl & intake system & LDV & experimental & $\mathrm{SR}=2.5-5$ & - & - \\
\hline $\begin{array}{c}\text { Hamamoto et al. } \\
\text { [32] }\end{array}$ & 1985 & SI & $78 \times 85$ & $600,900,1200$ & swirl & intake system & HWA, LDV & experimental & $\begin{array}{l}\mathrm{SR}=1.17,1.52 \\
2.21\end{array}$ & $\begin{array}{c}\text { burn duration } \\
\text { calculated with } \\
\text { turbulence intensity }\end{array}$ & - \\
\hline Nishiwaki [13] & 1985 & - & - & - & swirl & $\begin{array}{l}\text { shrouded valve, } \\
\text { directed and } \\
\text { helical ports }\end{array}$ & $\begin{array}{l}\text { steady flow } \\
\text { test }\end{array}$ & $\begin{array}{l}\text { numerical \& } \\
\text { experimental }\end{array}$ & $\begin{array}{c}\mathrm{SR}=1.8,2.4,2.5, \\
3.4\end{array}$ & - & - \\
\hline $\begin{array}{l}\text { Hall and Bracco } \\
\text { [33] }\end{array}$ & 1987 & SI & $82.6 \times 114.3$ & $600,1200,1800$ & swirl & intake system & LDV & experimental & $S R=2-6$ & $\begin{array}{c}\text { flame propagation } \\
\text { considerably faster } \\
\text { with swirl }\end{array}$ & - \\
\hline $\begin{array}{l}\text { Mikulec et al. } \\
{[53]}\end{array}$ & 1988 & SI & - & 1500 & swirl & $\begin{array}{l}\text { rotating intake } \\
\text { port }\end{array}$ & air flow meter & experimental & $\mathrm{SR}=0-2.8$ & $\begin{array}{c}\text { decrease in ignition } \\
\text { delay and combustion } \\
\text { duration, improvement } \\
\text { in combustion stability } \\
\end{array}$ & - \\
\hline $\begin{array}{c}\text { Arcoumanis and } \\
\text { Tanabe [14] }\end{array}$ & 1989 & CI & $93.7 \times 90.54$ & - & swirl & helical ports & LDV & experimental & $\mathrm{SR}=1.6-2.2$ & - & - \\
\hline $\begin{array}{c}\text { Kyriakides and } \\
\text { Glover [54] }\end{array}$ & 1989 & SI & $85.7 \times 86.0$ & & swirl & masked valve & LDA & experimental & $\mathrm{SR}=0.6,2.9$ & $\begin{array}{l}\text { higher turbulence } \\
\text { intensity leads to } \\
\text { faster combustion }\end{array}$ & - \\
\hline $\begin{array}{c}\text { Arcoumanis et al. } \\
{[7]}\end{array}$ & 1990 & SI & $73.5 \times 70$ & 1000 & tumble & $\begin{array}{l}\text { rotating intake } \\
\text { port }\end{array}$ & LDV & experimental & $\begin{array}{l}\mathrm{SR}=0, \mathrm{TR}=1.5 \\
\left(90^{\circ} \text { port }\right) \\
\mathrm{SR}=1, \mathrm{TR}=0.5 \\
\left(45^{\circ} \text { port }\right)\end{array}$ & - & - \\
\hline $\begin{array}{l}\text { Hadded and } \\
\text { Denbratt [9] }\end{array}$ & 1991 & SI & $96 \times 80$ & 1500 & tumble & $\begin{array}{l}\text { directed port, } \\
\text { combustion } \\
\text { chamber } \\
\text { shrouding } \\
\end{array}$ & LDV & experimental & $\begin{array}{c}\mathrm{TR}=0.58,0.88 \\
1.14,1.95\end{array}$ & $\begin{array}{c}\text { improvements in } \\
\text { combustion rate and } \\
\text { combustion stability }\end{array}$ & - \\
\hline Omori et al. [8] & 1991 & SI & $75.5 \times 82$ & 1000,1500 & tumble & shrouded valve & LDV & experimental & $\mathrm{TR}=1-4$ & - & - \\
\hline $\begin{array}{c}\text { Arcoumanis et al. } \\
{[21]}\end{array}$ & 1992 & SI & $85 \times 89$ & 1000 & tumble & cylinder heads & LDV & experimental & $\mathrm{TR}=0-2$ & - & - \\
\hline Floch et al. [22] & 1995 & SI & $88 \times 82$ & 2000 & swirl, tumble & $\begin{array}{l}\text { flow control } \\
\text { baffles }\end{array}$ & LDV & experimental & $\begin{array}{l}\mathrm{SR}=0-2.5 \\
\mathrm{TR}=0-2.5\end{array}$ & $\begin{array}{c}\text { good correlation } \\
\text { between turbulence } \\
\text { intensity and the delay } \\
\text { angle, stability } \\
\text { improved with swirl } \\
\text { and tumble, burn } \\
\text { period reduced with } \\
\text { increase of tumble, } \\
\text { but not change } \\
\text { different swirl level }\end{array}$ & - \\
\hline $\begin{array}{l}\text { Khalighi et al. } \\
\text { [19] }\end{array}$ & 1995 & SI & $92 \times 85$ & 1300 & swirl, tumble & shrouded valve & PTV & $\begin{array}{l}\text { numerical \& } \\
\text { experimental }\end{array}$ & $\begin{array}{l}\mathrm{SR}=0.75-2.29 \\
\mathrm{TR}=3.61-5.03\end{array}$ & $\begin{array}{c}\text { computed and } \\
\text { measured results show } \\
\text { same behavior for } \\
\text { flame shapes in later } \\
\text { burn } \\
\end{array}$ & - \\
\hline $\begin{array}{l}\text { Rutland et al. } \\
\text { [47] }\end{array}$ & 1995 & $\mathrm{CI}$ & $137.19 \times 165.1$ & 2100 & swirl & $\begin{array}{c}\text { modification } \\
\text { engine geometry }\end{array}$ & PIV & $\begin{array}{l}\text { numerical \& } \\
\text { experimental }\end{array}$ & $\mathrm{SR}=0.25$ & $\begin{array}{l}\text { enhanced mixing } \\
\text { promotes fast } \\
\text { combustion }\end{array}$ & $\begin{array}{l}\text { reduce both soot } \\
\text { and } \mathrm{NO}_{\mathrm{x}}\end{array}$ \\
\hline
\end{tabular}


Table 1 (continued)

\begin{tabular}{|c|c|c|c|c|c|c|c|c|c|c|c|}
\hline Researchers & Year & Ignition & $\begin{array}{l}\text { Bore } x \\
\text { stroke } \\
(\mathbf{m m})\end{array}$ & Speed (rpm) & In cylinder flow & $\begin{array}{l}\text { Generation of swirl, } \\
\text { tumble and squish }\end{array}$ & $\begin{array}{c}\text { Flow } \\
\text { measurement } \\
\text { techniques }\end{array}$ & $\begin{array}{c}\text { Numerical and/or } \\
\text { experimental } \\
\text { methods }\end{array}$ & $\begin{array}{c}\text { SR and/or } \\
\text { TR }\end{array}$ & $\begin{array}{l}\text { Effect of combustion } \\
\text { characteristics }\end{array}$ & $\begin{array}{c}\text { Effect of exhaust } \\
\text { emissions }\end{array}$ \\
\hline $\begin{array}{l}\text { Urushihara et } \\
\text { al. [41] }\end{array}$ & 1995 & SI & $82.5 \times 86$ & 1400,2000 & swirl, tumble & swirl control valve & LDV & experimental & $\begin{array}{l}S R=0-4 \\
\mathrm{TR}=0-7\end{array}$ & $\begin{array}{c}\text { strong correlation between } \\
\text { combustion duration and } \\
\text { turbulence intensity, tumble } \\
\text { promoted combustion }\end{array}$ & - \\
\hline $\begin{array}{l}\text { Stephenson et } \\
\text { al. [59] }\end{array}$ & 1996 & $\mathrm{CI}$ & $137.19 \times 162$ & 1600 & swirl & intake system & - & numerical & $S R=0-6$ & $\begin{array}{l}\text { the effect of swirl ratio on } \\
\text { ignition delay is strong only } \\
\text { for very large swirl ratios }\end{array}$ & $\begin{array}{c}\text { large swirl enhanced soot } \\
\text { oxidation and } \mathrm{NO}_{\mathrm{x}} \\
\text { formation } \\
\end{array}$ \\
\hline $\begin{array}{l}\text { Urushihara et } \\
\text { al. [20] }\end{array}$ & 1996 & SI & $83 \times 86$ & 1400 & swirl, tumble & $\begin{array}{l}\text { dual ports, shrouded } \\
\text { valves, swirl control } \\
\text { valves } \\
\end{array}$ & LDV & experimental & $\begin{array}{l}\mathrm{SR}=0-5, \\
\mathrm{TR}=0-5\end{array}$ & $\begin{array}{c}\text { most homogenous in } \\
\text { cylinder fuel mixture } \\
\text { obtained around ignition } \\
\text { timing by swirl control valve }\end{array}$ & $\begin{array}{c}\text { a low level of } \mathrm{NO}_{\mathrm{x}} \\
\text { obtained at the lean limit } \\
\text { over a wide range of fuel } \\
\text { injection timings }\end{array}$ \\
\hline Kang et al. [10] & 1997 & SI & $86 \times 86$ & 1000 & tumble & intake ports & LDV & experimental & - & $\begin{array}{c}\text { faster flame propagation, } \\
\text { stable combustion with } \\
\text { stronger tumble under lean } \\
\text { mixture } \\
\end{array}$ & (1) \\
\hline Zolver et al. [48] & 1997 & $\mathrm{CI}$ & $85 \times 88$ & 1400,2250 & swirl & piston bowl & - & $\begin{array}{l}\text { numerical \& } \\
\text { experimental }\end{array}$ & $\mathrm{SR}=0-3$ & $\begin{array}{l}\text { modifying volume and } \\
\text { restriction area of the bowl } \\
\text { cause some improvements in } \\
\text { combustion }\end{array}$ & $\begin{array}{l}\text { low NO emission for } \\
\text { partial load }\end{array}$ \\
\hline $\begin{array}{l}\text { Arcoumanis et } \\
\text { al. [56] }\end{array}$ & 1998 & SI & $83 \times 92$ & 850,1500 & tumble & $\begin{array}{l}\text { intake port with and } \\
\text { without metal sleeves }\end{array}$ & LDV & experimental & - & $\begin{array}{l}\text { flame propagation enhanced } \\
\text { and convection of the flame } \\
\text { far from the spark plug } \\
\text { reduced by the sleeved ports, } \\
\text { the position of the flame } \\
\text { more variable from one } \\
\text { cycle to the next by non- } \\
\text { sleeved ports } \\
\end{array}$ & $\begin{array}{l}\text { using sleeved ports } \mathrm{NO}_{\mathrm{x}} \\
\text { level reduced by part load } \\
\text { and } \mathrm{HC} \text { emissions not } \\
\text { significantly change with } \\
\text { and without sleeved ports }\end{array}$ \\
\hline $\begin{array}{c}\text { Auriemma et al. } \\
{[49]}\end{array}$ & 1998 & $\mathrm{CI}$ & $86 \times 75$ & $\begin{array}{l}1000,1500, \\
2000\end{array}$ & swirl, squish & $\begin{array}{l}\text { re-entrant bowl-in } \\
\text { piston }\end{array}$ & LDA & experimental & - & - & - \\
\hline $\begin{array}{c}\text { Kang and Baek } \\
{[39]}\end{array}$ & 1998 & SI & $56.5 \times 49.5$ & 500,1000 & tumble & intake ports & LDV & experimental & - & - & - \\
\hline Jeng et al. [40] & 1999 & $\mathrm{CI}$ & $92 \times 96$ & 2400 & tumble & $\begin{array}{l}\text { shrouded valve, bowl- } \\
\text { in-piston }\end{array}$ & $\begin{array}{l}\text { a high-speed } \\
\text { particle image } \\
\text { analyzer } \\
\text { (PIA) } \\
\end{array}$ & experimental & - & - & - \\
\hline Kang et al. [34] & 1999 & $\mathrm{CI}$ & $\begin{array}{l}141 \times 160 \\
137 \times 165\end{array}$ & 1000,1600 & swirl & $\begin{array}{l}\text { aligned and inclined } \\
\text { valve ports }\end{array}$ & LDV & experimental & $\begin{array}{c}\mathrm{SR}=0.52, \\
1.19\end{array}$ & - & - \\
\hline Li et al. [11] & 2000 & $\mathrm{CI}$ & Bore $=118$ & - & swirl & $\begin{array}{l}\text { directed and helical } \\
\text { ports }\end{array}$ & HWA & experimental & $\begin{array}{c}\mathrm{SR}=2 \\
\text { (directed } \\
\text { port), } \\
\mathrm{SR}=2.5-3.5 \\
\text { (helical port) }\end{array}$ & - & - \\
\hline $\begin{array}{l}\text { Achuth and } \\
\text { Mehta [38] }\end{array}$ & 2001 & SI & $\begin{array}{c}84.45 \times 89 \\
78 \times 83.6 \\
\end{array}$ & $\begin{array}{l}1000, \\
1500\end{array}$ & tumble & $\begin{array}{c}\text { Intake system, pentroof } \\
\text { chamber }\end{array}$ & - & numerical & $\mathrm{TR}=0-7$ & - & - \\
\hline Li et al. [17] & 2002 & SI & $80 \times 89$ & 1200 & tumble & masked valve & PIV & experimental & $\mathrm{TR}=0.5-1$ & - & - \\
\hline Yun et al. [35] & 2002 & - & $79 \times 81.5$ & - & swirl, tumble & Intake system & $\begin{array}{c}\text { Impulse swirl } \\
\text { meter }\end{array}$ & experimental & $\begin{array}{c}\mathrm{SR}=0-2.5 \\
\mathrm{TR}=0-2\end{array}$ & - & - \\
\hline Lee et al. [42] & 2003 & - & $81 \times 95$ & $400,600,800$ & swirl, tumble & $\begin{array}{c}\text { Intake flow control } \\
\text { valves } \\
\end{array}$ & PIV, PTV & experimental & $\mathrm{TR}=0-4$ & $\begin{array}{c}\text { tumble increased flame } \\
\text { propagation speed radically }\end{array}$ & - \\
\hline $\begin{array}{l}\text { Udayakumar et } \\
\text { al. [18] }\end{array}$ & 2003 & $\mathrm{CI}$ & $87.5 \times 110$ & 1500 & swirl & shrouded valve & - & experimental & - & - & $\begin{array}{l}\text { the shroud angle } \\
\text { between } 60^{\circ} \text { and } 80^{\circ} \text { is } \\
\text { optimum for reducing CO } \\
\text { and } \mathrm{NO}_{\mathrm{x}} \text { emissions }\end{array}$ \\
\hline
\end{tabular}


International Journal of Automotive Engineering and Technologies, IJAET 8 (2) 83-102

Table 1 (continued)

\begin{tabular}{|c|c|c|c|c|c|c|c|c|c|c|c|}
\hline Researchers & Year & Ignition & $\begin{array}{l}\text { Bore } x \\
\text { stroke } \\
(\mathbf{m m})\end{array}$ & Speed (rpm) & In cylinder flow & $\begin{array}{l}\text { Generation of swirl, } \\
\text { tumble and squish }\end{array}$ & $\begin{array}{c}\text { Flow } \\
\text { measurement } \\
\text { techniques }\end{array}$ & $\begin{array}{c}\text { Numerical and/or } \\
\text { experimental } \\
\text { methods }\end{array}$ & $\begin{array}{l}\text { SR and/or } \\
\text { TR }\end{array}$ & $\begin{array}{l}\text { Effect of combustion } \\
\text { characteristics }\end{array}$ & $\begin{array}{l}\text { Effect of exhaust } \\
\text { emissions }\end{array}$ \\
\hline Payri et al. [26] & 2004 & $\mathrm{CI}$ & 130x 150 & 1000 & swirl & intake port, piston bowl & LDV & $\begin{array}{l}\text { numerical \& } \\
\text { experimental }\end{array}$ & $S R=1-4$ & - & - \\
\hline $\begin{array}{l}\text { Selamet et al. } \\
\text { [57] }\end{array}$ & 2004 & SI & $87.5 \times 101$ & 1200,1600 & $\begin{array}{l}\text { swirl, tumble, } \\
\text { swumble }\end{array}$ & $\begin{array}{l}\text { intake runner } \\
\text { blockages }\end{array}$ & - & experimental & - & $\begin{array}{l}\text { in contrast to swirl and } \\
\text { swumble, tumble } \\
\text { considerably reduced burn } \\
\text { duration }\end{array}$ & $\begin{array}{c}\text { tumble and swirl reduced } \\
\mathrm{CO} \text { but increasing either } \\
\mathrm{NO}_{\mathrm{x}} \text { or } \mathrm{HC}, \text { swumble } \\
\text { reduced } \mathrm{NO}_{\mathrm{x}}, \mathrm{HC} \text {, and } \\
\mathrm{CO}\end{array}$ \\
\hline $\begin{array}{c}\text { Pipitone et al. } \\
{[23]}\end{array}$ & 2005 & - & Bore $=94$ & - & swirl & swirl control valve & $\begin{array}{l}\text { paddle-wheel } \\
\text { anemometer }\end{array}$ & experimental & $\mathrm{SR}=0-3.9$ & - & - \\
\hline Choi et al. [36] & 2006 & $\mathrm{CI}$ & $87 \times 102.4$ & 1700 & $\begin{array}{l}\text { swirl, tumble, } \\
\text { cross-tumble }\end{array}$ & $\begin{array}{l}\text { swirl chamber passage } \\
\text { hole }\end{array}$ & - & numerical & $\begin{array}{c}\mathrm{SR}=0-1.6, \\
\mathrm{TR}=0-1.4, \\
\mathrm{CTR} \text { (cross } \\
\text { tumble ratio) } \\
=0-1.4 \\
\text { (main } \\
\text { chamber) }\end{array}$ & - & - \\
\hline Lee et al. [24] & 2007 & SI & $86 \times 86$ & 1200,1250 & swirl, tumble & swirl control valves & LDV & experimental & $\begin{array}{c}\mathrm{SR}=0-1.088 \\
\mathrm{TR}=2.016- \\
2.224\end{array}$ & faster flame development & - \\
\hline $\begin{array}{c}\text { Micklow and } \\
\text { Gong [43] }\end{array}$ & 2007 & $\mathrm{CI}$ & $137.6 \times 165.1$ & 1700 & swirl, tumble & $\begin{array}{c}\text { intake system, piston } \\
\text { bowl }\end{array}$ & - & $\begin{array}{l}\text { numerical \& } \\
\text { experimental }\end{array}$ & $\begin{array}{l}\mathrm{SR}=-3-2, \\
\mathrm{TR}=0-2.1\end{array}$ & - & - \\
\hline $\begin{array}{c}\text { Huang et al. } \\
\text { [50] }\end{array}$ & 2008 & SI & $60 \times 66$ & 2000 & tumble & $\begin{array}{c}\text { flat and slightly } \\
\text { concave-crown pistons } \\
\end{array}$ & PIV & experimental & $\mathrm{TR}=-0.2-1.2$ & - & - \\
\hline $\begin{array}{c}\text { Gunabalan and } \\
\text { Ramprabhu } \\
{[27]}\end{array}$ & 2009 & $\mathrm{CI}$ & $87.5 \times 110$ & 1500 & swirl & $\begin{array}{l}\text { intake system, piston } \\
\text { bowl }\end{array}$ & - & numerical & $\mathrm{SR}=0-3.5$ & faster combustion process & $\begin{array}{l}\text { soot reduced but } \mathrm{NO}_{\mathrm{x}} \\
\text { increased }\end{array}$ \\
\hline $\begin{array}{c}\text { Rakopoulos et } \\
\text { al. [60] }\end{array}$ & 2010 & $\mathrm{CI}$ & $\begin{array}{l}85.73 x \\
82.55 \\
\end{array}$ & $\begin{array}{l}1500,2000, \\
2500\end{array}$ & squish & $\begin{array}{l}\text { cylinder-bowl } \\
\text { configurations }\end{array}$ & - & numerical & - & - & - \\
\hline $\begin{array}{l}\text { Ramajo et al. } \\
{[44]}\end{array}$ & 2011 & SI & $87 \times 68$ & - & swirl, tumble & $\begin{array}{l}\text { swirl and tumble } \\
\text { deflectors }\end{array}$ & $\begin{array}{c}\text { a rotary } \\
\text { honeycomb } \\
\text { swirl meter }\end{array}$ & $\begin{array}{l}\text { numerical \& } \\
\text { experimental }\end{array}$ & - & - & - \\
\hline $\begin{array}{c}\text { Bottone et al. } \\
{[37]}\end{array}$ & 2012 & $\mathrm{CI}$ & $79.5 \times 95.5$ & 1500 & swirl, tumble & $\begin{array}{l}\text { Intake system, piston } \\
\text { bowl }\end{array}$ & - & $\begin{array}{l}\text { numerical \& } \\
\text { experimental }\end{array}$ & $\begin{array}{c}\mathrm{SR}=-0.5-3 \\
\mathrm{TR}=-0.4-1.2\end{array}$ & - & - \\
\hline $\begin{array}{l}\text { Jaichandar and } \\
\text { Annamalai [61\} }\end{array}$ & 2012 & $\mathrm{CI}$ & $87.5 \times 110$ & 1500 & swirl, squish & $\begin{array}{l}\text { different combustion } \\
\text { chambers }\end{array}$ & - & experimental & - & $\begin{array}{l}\text { Improvement brake thermal } \\
\text { efficiency }\end{array}$ & $\begin{array}{l}\text { particulates, } \mathrm{CO} \text { and } \\
\text { unburnt } \mathrm{HC} \text { reduced, } \mathrm{NO}_{\mathrm{x}} \\
\text { slightly increased }\end{array}$ \\
\hline $\begin{array}{l}\text { Porpatham et } \\
\text { al. [55] }\end{array}$ & 2013 & SI & $87.5 \times 110$ & 1500 & swirl & masked valve & swirl meter & experimental & - & $\begin{array}{l}\text { extended misfire limit, } \\
\text { improved brake thermal } \\
\text { efficiency and power output }\end{array}$ & $\begin{array}{l}\mathrm{HC} \text { decreased and NO } \\
\text { increased }\end{array}$ \\
\hline Raj et al. [28] & 2013 & $\mathrm{CI}$ & $87.5 \times 110$ & 1500 & tumble & $\begin{array}{l}\text { different piston } \\
\text { configurations }\end{array}$ & - & numerical & $\mathrm{TR}=-1.5-1.5$ & - & - \\
\hline Wei et al. [62] & 2013 & $\mathrm{CI}$ & $135 \times 150$ & 1500 & swirl, squish & swirl chamber & - & numerical & $\mathrm{SR}=0.2-3.2$ & $\begin{array}{l}\text { affected the fuel/air } \\
\text { equivalence ratio in the } \\
\text { chamber }\end{array}$ & $\begin{array}{l}\text { NO and soot increased } \\
\text { with the rise in swirl ratio }\end{array}$ \\
\hline Li et al. [63] & 2014 & $\mathrm{CI}$ & $92 \times 93.8$ & 3600 & squish & piston bowl geometry & - & $\begin{array}{l}\text { numerical \& } \\
\text { experimental }\end{array}$ & - & $\begin{array}{l}\text { higher indicated work, } \\
\text { cylinder pressure with } \\
\text { change of engine speeds and } \\
\text { the bowl geometry }\end{array}$ & $\begin{array}{l}\text { NO increased and } \mathrm{CO} \\
\text { decreased according to } \\
\text { engine speeds and the } \\
\text { bowl shapes }\end{array}$ \\
\hline
\end{tabular}


Table 1 (continued)

\begin{tabular}{|c|c|c|c|c|c|c|c|c|c|c|c|}
\hline Researchers & Year & Ignition & $\begin{array}{l}\text { Bore } x \\
\text { stroke } \\
(\mathrm{mm})\end{array}$ & $\begin{array}{l}\text { Speed } \\
(\mathbf{r p m})\end{array}$ & $\begin{array}{l}\text { In cylinder } \\
\text { flow }\end{array}$ & $\begin{array}{l}\text { Generation of swirl, } \\
\text { tumble and squish }\end{array}$ & $\begin{array}{c}\text { Flow } \\
\text { measurement } \\
\text { techniques }\end{array}$ & $\begin{array}{c}\text { Numerical and/or } \\
\text { experimental } \\
\text { methods }\end{array}$ & SR and/or TR & $\begin{array}{l}\text { Effect of combustion } \\
\text { characteristics }\end{array}$ & $\begin{array}{c}\text { Effect of exhaust } \\
\text { emissions }\end{array}$ \\
\hline Taghavifar et al. [64] & 2014 & $\mathrm{CI}$ & $82.5 \times 82$ & 1500 & swirl, squish & $\begin{array}{l}\text { modifications in the bowl } \\
\text { radius and the outer bowl } \\
\text { diameter }\end{array}$ & - & $\begin{array}{l}\text { numerical \& } \\
\text { experimental }\end{array}$ & $\mathrm{SR}=3$ & $\begin{array}{l}\text { higher peak pressure but } \\
\text { combustion starting delayed to } \\
\text { the late expansion }\end{array}$ & $\begin{array}{c}\text { increase of the outer } \\
\text { bowl diameter resulted } \\
\text { in increase of NO } \mathrm{Nand}_{\mathrm{x}} \text { and } \\
\text { decrease of soot }\end{array}$ \\
\hline Zhang et al. [58] & 2014 & SI & $\begin{array}{c}82.5 \mathrm{x} \\
84.2\end{array}$ & 1500,2000 & tumble & variable tumble valve & - & experimental & $\mathrm{TR}=0-1.64$ & $\begin{array}{l}\text { improvement in fuel economy, } \\
\text { shortened combustion duration }\end{array}$ & $\begin{array}{c}\mathrm{NO}_{\mathrm{x}}, \text { CO decreased and } \\
\text { HC increased }\end{array}$ \\
\hline Bari and Saad [25] & 2015 & $\mathrm{CI}$ & $104 \times 108$ & 1500 & swirl & guide vane model & - & $\begin{array}{c}\text { numerical \& } \\
\text { experimental }\end{array}$ & - & $\begin{array}{l}\text { enhancing engine efficiency } \\
\text { and air-fuel ratio with } 35^{\circ} \text { vane } \\
\text { angle }\end{array}$ & $\begin{array}{c}\text { decreasing in } \mathrm{NO}_{\mathrm{x}} \text { and } \\
\mathrm{HC} \text { emissions with } 35^{\circ} \\
\text { vane angle }\end{array}$ \\
\hline $\begin{array}{c}\text { Harshavardhan and } \\
\text { Mallikarjuna [29] }\end{array}$ & 2015 & SI & $87.5 \times 110$ & 1500 & tumble & different piston shapes & - & numerical & $\mathrm{TR}=-0.2-0.2$ & - & - \\
\hline Zeng et al. [59] & 2015 & SI & $86 \times 86$ & 5500 & tumble & piston top contour & - & numerical & - & $\begin{array}{l}\text { A piston with a smoother top } \\
\text { surface strengthens the } \\
\text { turbulence kinetic energy at the } \\
\text { time of ignition, thereby } \\
\text { accelerating combustion and } \\
\text { increasing in-cylinder } \\
\text { temperature and pressure. }\end{array}$ & $\begin{array}{c}\text { higher in-cylinder } \\
\text { temperature and } \\
\text { pressure promote NO } \\
\text { emission, soot emission } \\
\text { decrease due to } \\
\text { subsequent } \\
\text { oxidation. }\end{array}$ \\
\hline Prabhakaran et al. [65] & 2016 & $\mathrm{CI}$ & $87.5 \times 110$ & 1500 & swirl & $\begin{array}{l}\text { piston bowl with different } \\
\text { tangential holes }\end{array}$ & - & $\begin{array}{l}\text { numerical \& } \\
\text { experimental }\end{array}$ & $\begin{array}{c}\mathrm{SR}=-3.5 \\
(3.5 \mathrm{~mm} \\
\text { tangential } \\
\text { hole })\end{array}$ & $\begin{array}{l}\text { proving better combustion with } \\
2.5 \mathrm{~mm} \text { tangential hole }\end{array}$ & $\begin{array}{l}\text { Increasing in } \mathrm{NO}_{\mathrm{x}} \text {, } \\
\text { decreasing } \mathrm{HC}, \mathrm{CO} \text { and } \\
\text { soot } 2 \mathrm{~mm} \text { and } 2.5 \mathrm{~mm} \\
\text { tangential holes }\end{array}$ \\
\hline $\begin{array}{l}\text { Ravi and Porpatham } \\
\text { [66] }\end{array}$ & 2017 & SI & $87.5 \times 110$ & 1500 & squish & $\begin{array}{l}\text { piston with different } \\
\text { squish area }\end{array}$ & $\begin{array}{c}\text { A positive- } \\
\text { displacement } \\
\text { type air flow } \\
\text { meter }\end{array}$ & experimental & - & $\begin{array}{l}\text { Increasing in brake power and } \\
\text { brake thermal efficiency with } \\
30 \% \text { squish area piston }\end{array}$ & $\begin{array}{l}\text { Increasing in NO and } \\
\text { reducing in } \mathrm{HC} \text { with } \\
30 \% \text { squish area piston }\end{array}$ \\
\hline Yan et al. [67] & 2017 & SI & $113 \times 140$ & 1300 & swirl & $\begin{array}{l}\text { reentrant piston bowl } \\
\text { with different diameter } \\
\text { ratio between chamber } \\
\text { throat and cylinder bore }\end{array}$ & - & $\begin{array}{l}\text { numerical \& } \\
\text { experimental }\end{array}$ & $\mathrm{SR}=-2.4$ & $\begin{array}{l}\text { thermal efficiency improved } \\
\text { about } 1.5 \% \text { at full load and 3\% } \\
\text { at medium and high load by } \\
\text { reentrant piston bowl with } \\
\text { diameter ratio of } 0.5 \\
\end{array}$ & - \\
\hline Zhou et al. [60] & 2017 & SI & $80.5 \times 78.5$ & 2000 & swirl, tumble & Port blocker & $\begin{array}{l}\text { swirl and } \\
\text { tumble paddle } \\
\text { wheels }\end{array}$ & experimental & - & $\begin{array}{l}\text { intake tumble enhanced the } \\
\text { lean burn limit without high the } \\
\text { coefficient of cyclic variation. }\end{array}$ & $\begin{array}{l}\text { specific emissions of } \\
\mathrm{CO}, \mathrm{CO}, \mathrm{HC} \text { and } \mathrm{NO} \mathrm{X}_{\mathrm{X}} \\
\text { reduced by } 5.8 \%, \\
72.2 \%, 12.0 \% \text { and } \\
85.3 \%, \text { respectively }\end{array}$ \\
\hline Calik et al. [68] & 2018 & $\mathrm{CI}$ & $104 \times 114$ & 2500 & swirl, tumble & $\begin{array}{l}\text { MR-2 type combustion } \\
\text { camber }\end{array}$ & - & numerical & $\begin{array}{l}\mathrm{SR}=4,8,12 \\
16 \text { (initial } \\
\text { swirls) }\end{array}$ & $\begin{array}{l}\text { heat release rate and cylinder } \\
\text { pressure increases slightly with } \\
\text { Increase of swirl ratio for same } \\
\text { spray umbrella angle }\end{array}$ & - \\
\hline Hamid et al. [69] & 2018 & $\mathrm{CI}$ & $84 \times 90$ & 2000 & swirl, tumble & $\begin{array}{l}\text { different piston bowl } \\
\text { geometry }\end{array}$ & - & numerical & $\begin{array}{c}\mathrm{SR}=2.5-3, \\
\mathrm{TR}=-0.2, \\
\mathrm{CTR}=-1.2 \text { at } \\
360^{\circ} \mathrm{CA}\end{array}$ & - & - \\
\hline Baratta et al. [70] & 2019 & SI & - & 2000,3500 & tumble & $\begin{array}{l}\text { Intake valve masking } \\
\text { surface, different piston } \\
\text { shapes (CR=12,13,14) }\end{array}$ & - & $\begin{array}{l}\text { numerical \& } \\
\text { experimental }\end{array}$ & $\begin{array}{c}\mathrm{TR}=\text { nearly } \\
1.5 \text { with mask }\end{array}$ & $\begin{array}{c}\text { piston configuration with } \\
\mathrm{CR}=13 \text { enhancing engine } \\
\text { performance at full load and } \\
\text { developing fuel consumption at } \\
\text { partial load. } \\
\end{array}$ & - \\
\hline Karthickeyan [71] & 2019 & $\mathrm{CI}$ & $87.5 \times 110$ & 1500 & swirl, squish & $\begin{array}{l}\text { different piston bowl } \\
\text { geometry }\end{array}$ & - & experimental & - & $\begin{array}{l}\text { higher thermal efficiency, in- } \\
\text { cylinder pressure and heat } \\
\text { release rate obtained with TCC } \\
\text { engine }\end{array}$ & $\begin{array}{l}\text { lower } \mathrm{CO}, \mathrm{HC}, \mathrm{NO}_{\mathrm{x}} \text { and } \\
\text { smoke obtained with } \\
\text { TCC engine }\end{array}$ \\
\hline
\end{tabular}


$(\mathrm{SR})_{1}=\omega_{\mathrm{s}} /(2 \pi \mathrm{N} / 60)$

$(\mathrm{SR})_{2}=\mathrm{u}_{\mathrm{t}} / \overline{\mathrm{U}}_{\mathrm{p}}$

where $\mathrm{SR}$ is swirl ratio, $\mathrm{N}$ is engine speed, rpm, $\mathrm{u}_{\mathrm{t}}$ is tangential flow velocity, $\mathrm{m} / \mathrm{s}$, and $\overline{\mathrm{U}}_{\mathrm{p}}$ is average piston velocity, $\mathrm{m} / \mathrm{s}, \omega_{\mathrm{s}}$ is swirl angular speed, $\mathrm{rad} / \mathrm{s} . \omega_{\mathrm{s}}$ is expressed as the ratio of angular momentum to the moment of inertia of swirl flow:

$\omega_{\mathrm{s}}=\frac{L_{\mathrm{s}}}{\mathrm{I}_{\mathrm{s}}}$

where $\mathrm{L}_{\mathrm{s}}$ is the angular momentum of swirl flow and $I_{s}$ is the moment of inertia of swirl flow expressed as

$I_{s}=\int r_{s}^{2} d m$ for a cylinder $I_{s}=\frac{m^{2}}{8}$

where $\mathrm{m}$ is mass of in-cylinder flow, $\mathrm{kg}, \mathrm{r}_{\mathrm{s}}$ is the perpendicular distance from $m$ to the swirl axis, and B is bore of cylinder. During the cycle some swirl flow decays due to friction, but most of it continues through the compression, combustion and expansion strokes. Ignoring friction, angular momentum of swirl is conserved.

A tumble ratio is the dimensionless parameter used to characterize the magnitude of tumble flow expressed as

$\mathrm{TR}=\omega_{\mathrm{t}} /(2 \pi \mathrm{N} / 60)$

where TR is tumble ratio and $\omega_{t}$ is angular speed of tumble, $\mathrm{rad} / \mathrm{s} . \omega_{\mathrm{t}}$ is defined as the ratio of angular momentum to the moment of inertia of tumble:

$\omega_{t}=\frac{L_{t}}{I_{t}}$

where $L_{t}$ is the angular momentum of tumble flow and $I_{t}$ is the moment of inertia of tumble flow expressed as

$I_{t}=\int r_{t}^{2} d m$

where $r_{t}$ is the perpendicular distance from $m$ to the tumble axis. During compression, because of the upward movement of the piston, $I_{t}$ decreases when $r_{t}$ decreases as seen in Eq. (6). $\omega_{t}$ will then increase for constant $\mathrm{L}_{\mathrm{t}}$. Therefore piston motion plays a key role in compressing the tumble flow and increase of turbulence level at the end of compression stroke [1].

On the other hand, the quantity of squish in the cylinder of an engine is measured by the squish ratio, SQ, defined as [3]
$\mathrm{SQ}=\frac{\mathrm{A}_{\text {squish }}}{\mathrm{A}_{\text {total }}}$

where $\mathrm{A}_{\text {squish }}$ is the projected squish area, $\mathrm{A}_{\text {total }}$ is the projected piston area, as shown in Fig. 2.

$\mathrm{A}_{\text {total }}=\mathrm{A}_{\text {squish }}+\mathrm{A}_{\text {bowl }}$

where $A_{\text {bowl }}$ is the projected bowl area. The level of squish is also determined by the piston to head clearance at TDC. In order to obtain good result, Taylor suggested that the clearance should be smaller than 0.005 times the bore [4].

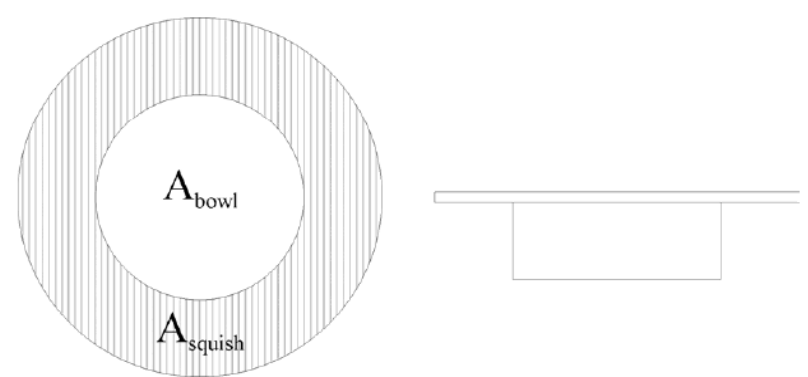

Fig. 2. Defination of squish areas [3]

\subsection{Generation of swirl, tumble and squish flows}

In this section, different mechanisms to produce swirl and tumble flows by intake system and squish flow by modifying the chamber at the end of the compression process are presented.

\subsubsection{Directed ports}

In this method, port is oriented to direct the flow in a desired tangential direction through the valve opening area. Numerous researchers used to directed ports to produce swirl and tumble [511]. Wigley et al. [5] reported that different flow characteristics were found between a machined directed port and a cast helical port. They showed that the directed port produced higher peak velocities and velocity gradients expense of two main vortices whereas the helical port produced more order flow which approached simple solid body rotation. Arcoumanis et al. [7] investigated that the flow generated by rotating the intake port at $90^{\circ}$ and $45^{\circ}$ to the orientation of directed ports as shown in Fig. 3.

They illustrated that the $90^{\circ}$ port produced a pure tumble motion, with a maximum tumbling vortex ratio of 1.5 at $295^{\circ}$ crank angle (CA), zero swirl, and $42 \%$ turbulence augmentation relative to the standard directed port, whereas the $45^{\circ}$ port brought about a combined tumble-swirl pattern with a maximum tumble ratio of 0.5 at $285^{\circ} \mathrm{CA}$, swirl ratio of 1.0 at TDC, and 
turbulence enhancement of $24 \%$. On the other hand, Omori et al. [8] showed that with a tumble port in which the flow directed to the exhaust valve side of the combustion chamber, mean discharge coefficient tended to decrease as compared with a conventional port. Therefore, optimum directed port design is required to promote turbulence intensity.
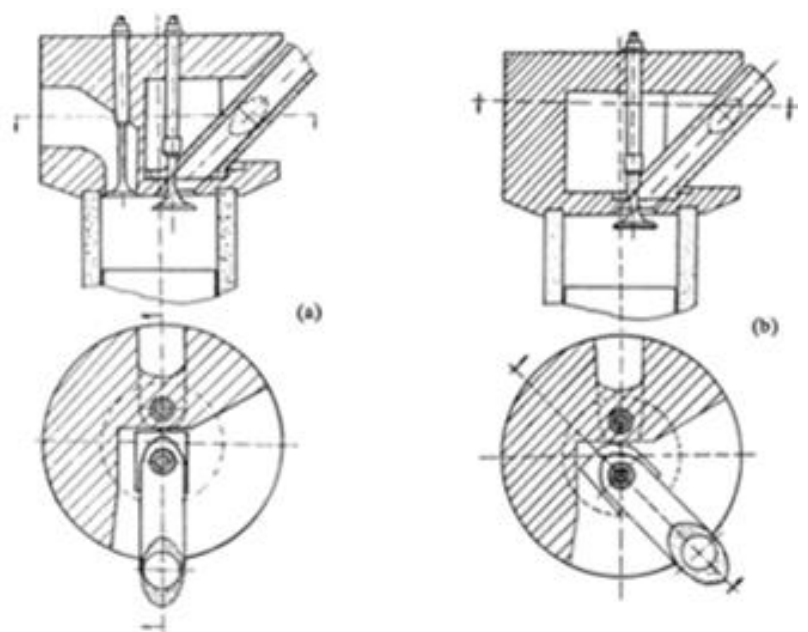

(b)

Fig. 3. Directed port geometries: (a) $90^{\circ}$ port orientation, (b) $45^{\circ}$ port orientation [7]

\subsubsection{Helical ports}

In helical ports as shown in Fig. 4, higher flow discharge is usually obtained compared with directed ports for equivalent levels of swirl since the whole periphery of the valve opening area can be fully utilized.

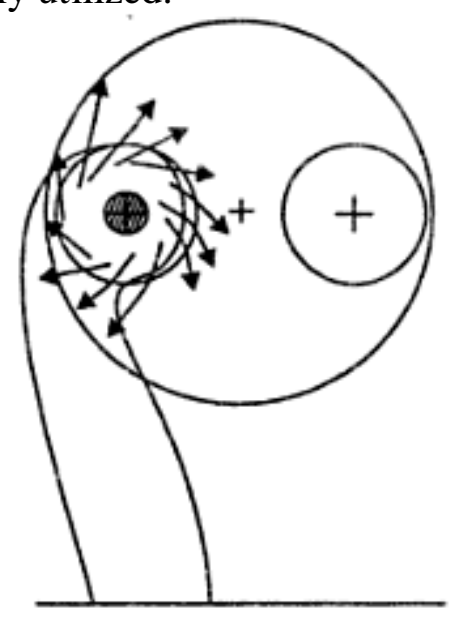

Fig. 4. Helical Ports [12]

Hence these ports provide higher volumetric efficiencies in the low-to-mid speed range of the engine. Also, they are less sensitive to their position relative to cylinder axis because the generation of swirl depends mainly on the port geometry above the valve and not how it enters the cylinder [12]. Some researchers examined effect of arrangement and orientation of helical ports on swirl flow $[6,11,13,14]$. Arcoumanis et al. [14] investigated the effect of inlet port design on swirl generation for four helical ports in Direct Injection (DI) diesel engines. They reported that at lower valve lifts, the pre-valve swirl component (generated by helical shape of port) of the total angular momentum played the significant role in producing swirl but its contribution decreased at higher valve lift. However, increasing valve lifts, the directional component of the total angular momentum became a significant contributor to generate swirl in the cylinder.

\subsubsection{Shrouded or masked valve and masked cylinder head}

Both shroud and mask partially obstruct the flow through the intake valve. The shroud is part of the valve or the cylinder head whereas the mask is fixed rigidly to the valve seat. Intake valve shrouding and masking can cause increasing rotating flow in the cylinder expense of reducing volumetric efficiency considerably [15]. Also, masked valve increases cost and weight and causes distortion and valve rotation. Therefore, masking on the valve is a limited for application in the engine production. More practical approach is building a mask on the cylinder head around part of the inlet valve perimeter to produce swirl. The mask can easily be integrated in the cylinder head casting method [16]. In order to enhance tumble motion, Li et al. [17] carried out experiments by using a single-cylinder Hydra engine whose intake valve seats were shrouded between the two intake valves and chamber wall along edge of the valve seats (masked area) as shown in Fig. 5.

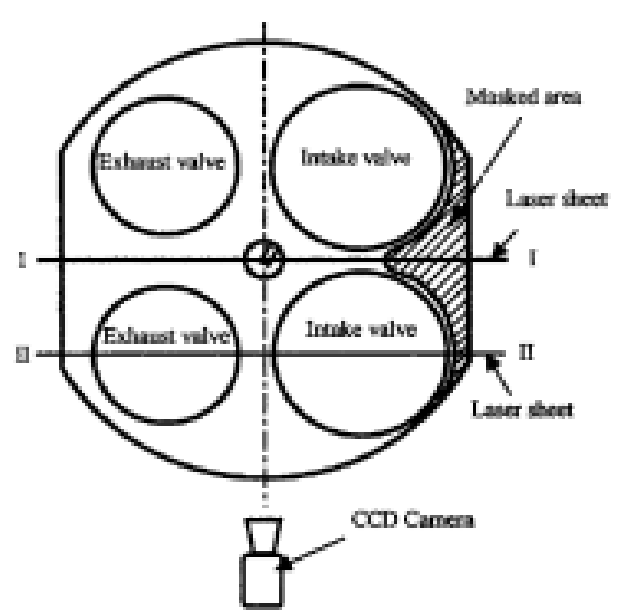

Fig. 5. The combustion chamber with masked area and high-resolution charge coupled device (CCD) [17] 
However, the shrouding of inlet valve permits the finding of the best tangential direction by turning the valve above the centerline. Several researchers also used the valve shrouding method to amplify turbulence generation [1820]. Udayakumar et al. [18] reported that shrouded valve used in diesel engine determined the intensity of swirl generated during suction stroke and helped in reducing the emissions.

\subsubsection{Flow blockages and valves}

Another approach of producing in-cylinder flow is to place flow blockages or valves in the intake duct. Different type valves and blocking materials were studied to generate swirl and tumble [21-25]. Arcoumanis et al. [21] showed that change of the inlet ports by partial blocking of their lower section enhanced the strength of the induction-generated tumbling vortex expense of decrease by 20 per cent in the discharge coefficient. Floch et al. [22] designed several baffle sizes and shapes placed between the intake manifold and the cylinder head to induce various in-cylinder flow fields to improve turbulence and combustion characteristics.

Pipitone et al. [23] analyzed the flow characteristics by using swirl control valve (SCV) method and different lifts (DL) method. They showed that in the SCV method, swirl ratio had a range from zero to 0.58 , whereas the DL arrangement increased swirl ratio up to 3.9. Lee et al. [24] examined the effects of tumble and swirl flow produced different swirl control valves as shown in Fig. 6 on early flame propagation in a four-valve SI engine under lean mixture conditions with different inlet ports of different entry angles such as $25^{\circ}, 20^{\circ}$, and $15^{\circ}$. They found that a correlation existent between the higher tumble during induction and turbulence levels at the time of ignition caused rapid flame development.

Bari et al. [25] proposed the guide vane located in front of intake manifold with varied vane angles to enhance performance and emissions in a biodiesel fueled CI engine by using SOLIDWORKS and ANSYS-CFX. The results showed that the in-cylinder airflow parameters such as turbulence kinetic energy, vorticity and swirling strength enhanced by using a vane angle in the range of $31.5^{\circ}-42.9^{\circ}$.

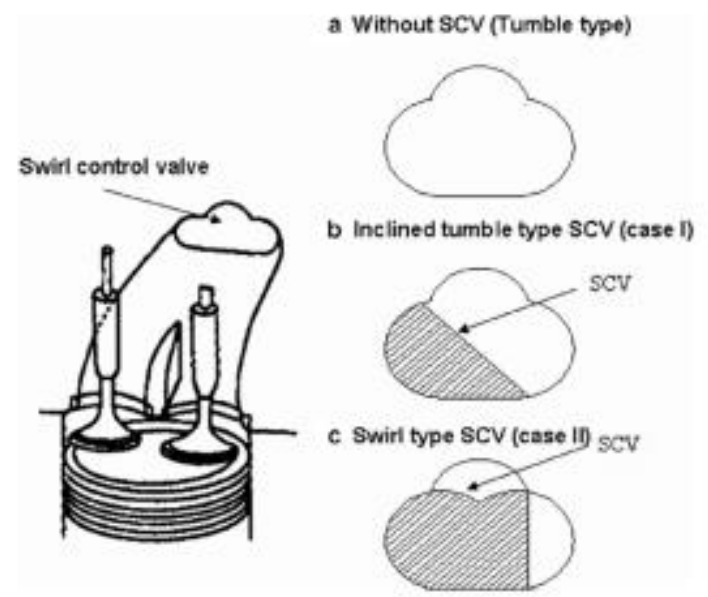

Fig. 6. Examples of swirl control valve (SCV) geometry [24]

\subsubsection{Squish generation methods}

In squish generation methods, the air or air-fuel mixture occupying the volume at the outer radius of the cylinder is forced radial inward into cylinder head cavity with wedge shape and/or a piston bowl as shown in Fig. 7 (a) and (b). This outer volume is reduced to near zero when portion of the piston face closed to cylinder head and the volume remaining in the cylinder is called as a clearance volume at TDC. In a modern combustion chamber, the clearance volume is generally near the centerline of the cylinder.
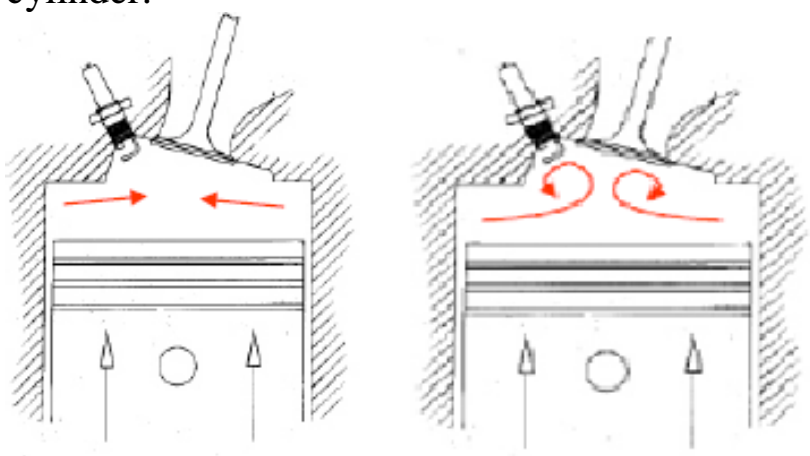

(a)
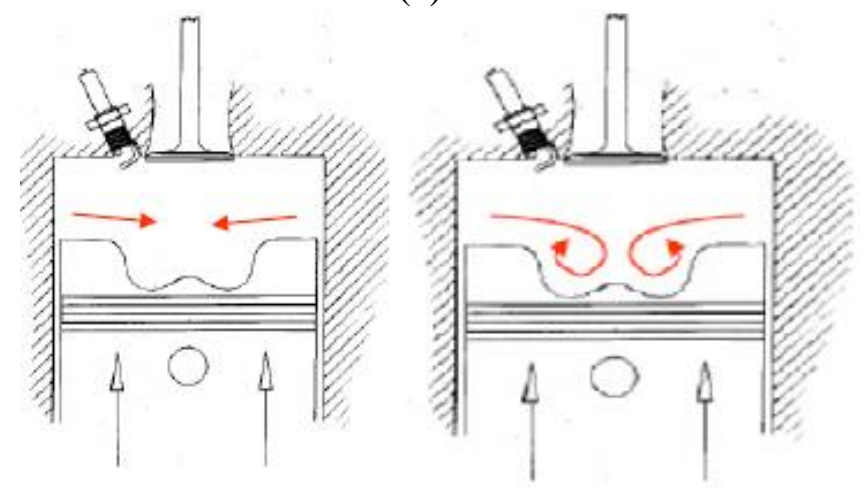

(b)

Fig. 7. Squish flow: (a) cylinder head cavity with wedge shape, (b) piston bowl 
Various piston bowl shapes was used to examine effect of squish on turbulence near TDC [26-29]. Payri et al. [26] examined the influence of the five different piston bowl geometries of a DI diesel engine on the flow field during intake and compression strokes numerically. It was concluded that the piston geometry had little influence on the in-cylinder flow during the intake stroke and the first part of the compression stroke but the bowl geometry played a critical role near TDC and in the early stage of the expansion stroke by controlling both the ensemble-averaged mean and the turbulence velocity fields. Gunabalan et al. [27] also calculated the flow characteristics of three different bowl configurations in DI diesel engine by using STAR CD. They observed that when the piston moved towards Top Dead Centre (TDC), the bowl geometry had an important influence on air flow therefore resulted in better mixing and better combustion and soot emission reduced expense of higher $\mathrm{NO}_{\mathrm{x}}$ emission.

\section{Turbulence Enhancement with Swirl, Tumble and Squish Flows}

Swirl, tumble and squish flows enhance turbulence intensity during late compression by breaking down these flows to small scale turbulent eddies. This provides increase of turbulent flame speed and so acceleration of burning rate. This section describes characteristics of turbulence and reviews turbulence generation techniques with swirl, tumble and squish flows in gasoline and diesel engines by using available experimental and numerical studies.

\subsection{Turbulence}

In internal combustion engines, the flow is periodic. Since the flow pattern alters with crank angle, it is unsteady. The instantaneous flow velocity at a specific crank angle position $\theta$ in a particular cycle is [16].

$$
\mathrm{U}(\theta, \mathrm{i})=\overline{\mathrm{U}}(\theta, \mathrm{i})+\mathrm{u}(\theta, \mathrm{i})
$$

where $\bar{U}(\theta, i)$ and $u(\theta, i)$ are the mean and fluctuating velocity at a specific crank angle position $\theta$ in a particular cycle i. Because of cycle-to-cycle variation, the ensemble-averaged velocity for the average of large number measurements taken at the same crank angle is calculated as

$$
\overline{\mathrm{U}}_{\mathrm{EA}}(\theta)=\frac{1}{\mathrm{n}} \sum_{\mathrm{i}}^{\mathrm{n}} \mathrm{U}(\theta, \mathrm{i})
$$

where $\mathrm{n}$ is number of cycles in available data. The difference between the mean velocity in a particular cycle and the ensemble-averaged mean velocity is defined as the cycle-by-cycle variation in mean velocity, $\hat{U}(\theta, i)$ can be written as

$$
\hat{\mathrm{U}}(\theta, \mathrm{i})=\overline{\mathrm{U}}(\theta, \mathrm{i})-\overline{\mathrm{U}}_{\mathrm{EA}}(\theta)
$$

The instantaneous velocity in Eq. (9) can be written as three components as shown in Fig. 8.

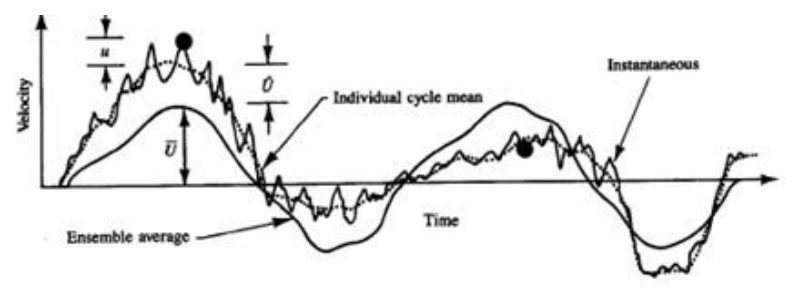

Fig. 8. The change of velocity during a two stroke engine cycle [16]

$$
\mathrm{U}(\theta, \mathrm{i})=\overline{\mathrm{U}}_{\mathrm{EA}}(\theta)+\hat{\mathrm{U}}(\theta, \mathrm{i})+\mathrm{u}(\theta, \mathrm{i})
$$

The turbulent intensity, $u_{t}$, at a specific crank angle position $\theta$ is determined by ensembleaveraging

$\mathrm{u}_{\mathrm{t}}(\theta)=\left[\frac{1}{\mathrm{n}} \sum_{\mathrm{i}=1}^{\mathrm{n}} \mathrm{u}^{2}(\theta, \mathrm{i})\right]^{1 / 2}$

On the other hand, Reynolds decomposition for statistically steady flow is

$$
\mathrm{U}(\mathrm{t})=\overline{\mathrm{U}}+\mathrm{u}(\mathrm{t})
$$

where $\mathrm{t}$ is time, $\overline{\mathrm{U}}=\frac{1}{\Delta \mathrm{t}} \int_{\mathrm{t}_{1}}^{\mathrm{t}_{2}} \mathrm{U}(\mathrm{t}) \mathrm{dt}$ is the mean velocity over the time interval from $t_{1}$ to $t_{2}$ and $\mathrm{u}(\mathrm{t})$ is the fluctuating component. The turbulent fluctuation intensity is generally defined as in regards to the root-mean-square (rms) of the fluctuations

$$
\mathrm{u}_{\mathrm{t}}=\mathrm{u}_{\mathrm{rms}}=\sqrt{\overline{\mathrm{u}^{2}}} \text { where } \overline{\mathrm{u}^{2}}=\frac{1}{\Delta \mathrm{t}} \int_{\mathrm{t}_{1}}^{\mathrm{t}_{2}}(\mathrm{u}(\mathrm{t}))^{2} \mathrm{dt}
$$

At the end of compression when the piston is at TDC, the turbulence intensity is approximately one-half the mean piston speed, $\overline{\mathrm{U}}_{\mathrm{p}}$

$\mathrm{u}_{\mathrm{t}}=\frac{1}{2} \overline{\mathrm{U}}_{\mathrm{p}}$ 


\subsection{Swirl flow}

Swirl is used to speed up to combustion process in SI engines and to increase faster mixing between air and fuel in CI and some stratified charge engines [16]. This flow regarded as a two dimensional solid body rotation is generated by intake system. In spite of some decaying due to friction during the engine cycle, it usually continues through the compression, combustion, and expansion strokes. The swirl flows require energy to produce the vortex during the intake stroke. This energy is mainly related to the kinetic energy of the gases entering the cylinder through the inlet valve. To promote swirl intensity, the gas velocities in the inlet valve must be high and a small cross section area must be required at the inlet valve. Therefore, optimum solution must be made between cross sectional area to be large for adequate intake flow at high engine speeds and to be small for generating a high gas velocity for a strong swirl. Similar requirements also exist for a tumble flow. Since flow pattern is strainfree, swirl is foreseen to have insignificant influence on turbulence increase in the bulk of the flow. However turbulence generated in the wall boundary can be transported through bulk flow by diffusion and swirl-driven secondary flow [15]. Turbulence is also generated by protruding objects such as off-centre spark plugs and valve heads because of surface shear stress and vortex shedding. Besides this, if the swirl flow combines with the squish flow, the rotational speed of the flow increases as the piston approaching TDC. Therefore, swirl promotes turbulence production especially late in the compression stroke.

Moreover, reduction of swirl in an engine cylinder during compression stroke was relatively small so that the overall angular momentum of swirl vortex is nearly conserved and swirl motion promoted turbulence level at TDC of combustion [30-35]. Liou et al. [31] examined mean velocity, turbulence intensity in a ported engine with flat head and piston, motored at 1200, 1800 and $2400 \mathrm{rpm}$ both with and without swirl. They reported that the turbulence measurements near TDC both with and without swirl resulted in relatively homogeneous turbulence intensity whereas higher turbulence intensity and lower cyclic fluctuations in the mean velocity were obtained with swirl. Choi et al. [36] investigated effect of swirl chamber type diesel engine passage hole area and angle on the turbulent flow using VECTIS CFD code. The results showed that the swirl ratio of the swirl chamber increased linearly as the passage hole area decreased and magnitude of kinetic energy depended on air flow velocity changed based on different shape of passage hole. On the other hand, Bottone et al. [37] studied Reynolds Averaged NavierStokes (RANS), Detached eddy simulations (DES) and Large-Eddy Simulation (LES) methods for multi-cycle simulations of incylinder flow with a realistic engine geometry by using STAR-CD CFD code. They demonstrated that the intensity of the cycle-tocycle variations in the swirl and tumble number was comparable to the DES and LES solutions.

\subsection{Tumble flow}

Tumble flow is characterized by the charge rotating about an axis parallel to the crank shaft. During late compression, tumble breaks down into small scale eddies due to the change in the aspect ratio caused by the piston movement and this leads to enhance turbulence intensity preignition [7, 24]. In general, tumble motion divides into four distinct phases such as vortex generation, stabilization, spin-up and decay [38]. The vortex generation phase lasts during intake process (from TDC to BDC). In this phase, the intake jet flow orientation is mainly controlled by port geometry and the combustion chamber and large-scale rotating flow patterns are created by interacting with cylinder walls and moving piston. After the first peak tumble, this flow decays considerably end of the phases due to friction at the cylinder wall. Vortex stabilization phase exists between intake BDC and the closing of the intake valve. In this stage, the rate of decay trends to diminish noticeably because of the upward movement of the piston. The vortex spin-up phase continues between intake valve closure and the second peak of tumble. The compression of vortex by the upward-moving piston causes reduction of its size, so tumble angular speed rises because of conserving angular momentum. The vortex decay phase occurs between the second peak and compression TDC. The vortex squeezed by piston and cylinder head results in its 
breakdown to the smaller vortices and turbulence generates.

Kang et al. [39] investigated the formation and decay mechanisms of tumble and its effects on turbulence characteristics by the LDV measurements for two different intake ports. They reported that in the case of the tumble port, the turbulence intensities at the cylinder center $(\mathrm{r}=0)$ and $9 \mathrm{~mm}$ offset point $(\mathrm{r}=9)$ became to be same level when the piston approached TDC, whereas in the conventional port turbulence at the center was still lower than that at $9 \mathrm{~mm}$ offset point by about $40 \%$ as shown in Fig. 9 . This demonstrated that the distribution in homogeneous turbulence increased with tumble flow near TDC. Jeng et al. [40] examined the quality of the tumbling motion, especially for the engine with a piston bowl by using a high-speed particle image analyzer (PIA) system. They concluded that adding a shroud to the intake valve helped the generation of large-scale tumbling motion and maintenance of the tumbling flow pattern but the use of bowl-in piston showed no immediate help in the generation and the maintenance of the tumbling flow pattern.

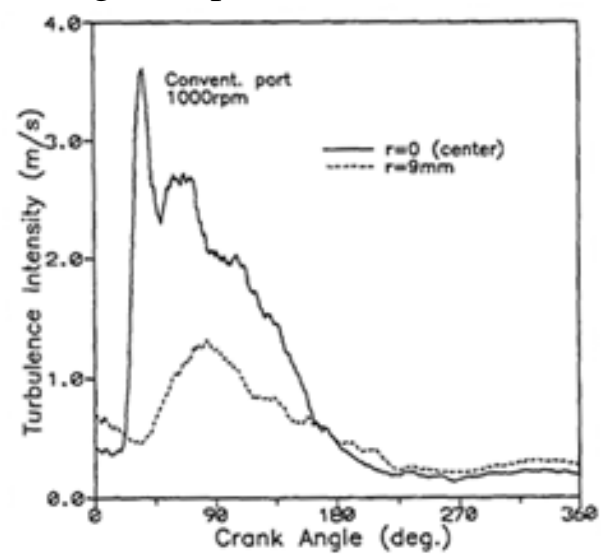

(a) Conventional port

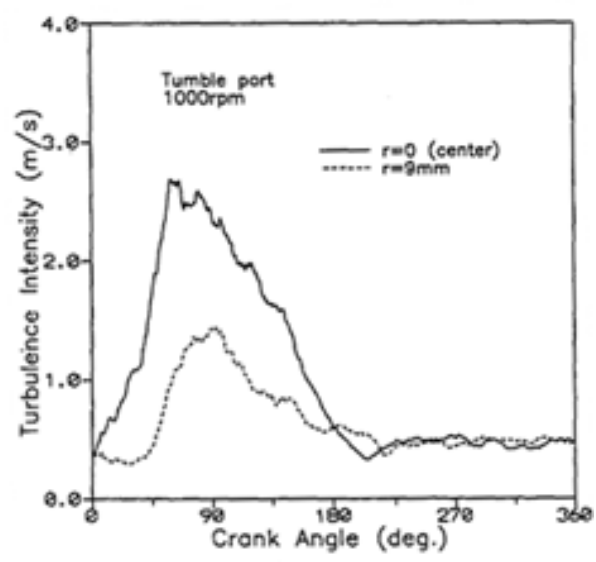

(b) Tumble port

Fig.9. Turbulence intensity variations at different positions for the two intake ports [39]
Recently, a combined swirl and tumble flows have been used in both SI and CI engines [22, 41-44]. Floch et al. [22] analyzed the effect of tumble and swirl on turbulence and combustion by means of flow-control baffle placed between the intake manifold and the cylinder head. They concluded that with an increase of the tumble intensity, higher turbulence intensity occurred before the end of the compression stroke where turbulence intensity scaled with the intake tumble intensity but not scaled with the intake swirl intensity. Urushihara et al. [41] examined combinations of swirl and tumble flow generated by 13 types of swirl control valve tested by using impulse steady flow rig and LDV. They pointed that tumble generated greater turbulence in the combustion chamber than swirl at an identical angular momentum measured in the steady flow test.

Likewise, Lee et al. [42] analyzed the effects of tumble and swirl flows produced a swirlintensifying valve (SIV) and a tumble intensifying-valve (TIV) on the turbulence scale by using the single-frame PTV and the twocolor PIV during the intake and compression processes in SI engine. It is found that the TIV generated larger tumble ratio and so turbulent intensity than SIV near the spark timing and the flame propagation speed increased in swirl and tumble flow fields with a lean air-fuel ratio. Furthermore, Micklow et al. [43] investigated the intake and in-cylinder flow field of a fourvalve DI-CI engine using a three-dimensional unsteady turbulent compressible Navier-Stokes solver, KIVA3V. They observed that the formation, improvement, and break-up of tumble flow contributed to the rise of turbulent kinetic energy at the end of the compression stroke.

\subsection{Squish flow}

Squish being a radial motion towards the centerline of the cylinder causes tumble motion when piston approaching TDC and then generates turbulence by breaking down small scale eddies similar to swirl and tumble. This flow increases turbulence level because of shear between the high velocity jets and the lower velocity fluid in the cavity in the cylinder head and the piston. Squish flows are used as mechanisms to speed flame front when the piston reaching TDC. It can also reduce cycle-to cycle variations which 
are inherent in internal combustion engines. But excessive squish can cause large amounts of unburnt gases in the exhaust. This unburned gas leads to wasted fuel and decrease of engine performance. So when using the squish to enhance combustion, levels of unburnt charge produced by this flow must be considered. Excessive squish can also result in problems with engine knock examined by Towers et al. [45]. Squish is often ineffective as a turbulence enhancement mechanism by itself for high performance SI engines [46]. The high levels of swirl combined with squish generate the turbulence and a toroidal vortex produced in the bowl and both of them contributes to mixing fuel and enhancing combustion [3].

Most researchers [25-29, 47-50] agreed that to obtain optimum design for a combustion chamber in SI and diesel engines, squish must be combined with other flows such as tumble and swirl. Zolver et al. [48] studied the impact of piston bowl geometry on flow characteristics during intake, compression, injection and combustion processes in a turbocharged DI diesel engine using Kiva-Multi-Block code. It was concluded that modifying volume and restriction area of the bowl brought some improvements in combustion. On the other hand, Auriemma et al. [49] examined the flow field behavior within a reciprocating engine equipped with a reentrant bowl-in piston by LDA measurements. They reported that radial inward motion was observed during the last part of compression and a peak was reached before TDC confirming theoretical studies predicted maximum squish velocities few degrees before TDC for bowl-in-piston chambers.

Raj et al. [28] studied four piston configurations such as flat, inclined, centre bowl and inclined offset bowl pistons using STAR-CD CFD and the results were compared with experimental data obtained PIV. It was concluded that a centre bowl on flat piston was a better configuration to have a good tumble ratio, turbulent kinetic energy and length scale and also to increase the energy efficiency of the engine. Recently, Harshavardhan et al. [29] performed numerical analysis on DI spark ignition engine using different piston shapes such as flat, flat-withcenter-bowl, inclined and inclined with-centerbowl pistons to analyze in-cylinder air flows and air-fuel interaction. They also obtained similar results with Raj et al that the flat-with-centerbowl piston engine had greater tumble ratio and turbulent kinetic energy resulted in better airfuel mixture at the time of injection and ignition when comparing other piston configurations.

\section{Effect of In-Cylinder Flow on Combustion and Emission}

In this section, how turbulence generating by swirl, tumble and squish flows in internal combustion engine affects combustion characteristics and exhaust emission is discussed.

\subsection{Combustion with swirl, tumble and squish}

As piston moving near TDC of compression, swirl and tumble flows persisting during intake and compression and squish flow produced end of the compression start breaking down into small scale eddies. This leads to augment turbulence intensity which causes wrinkling and growth of the flame front surface area in SI engine as shown in Fig. 10.
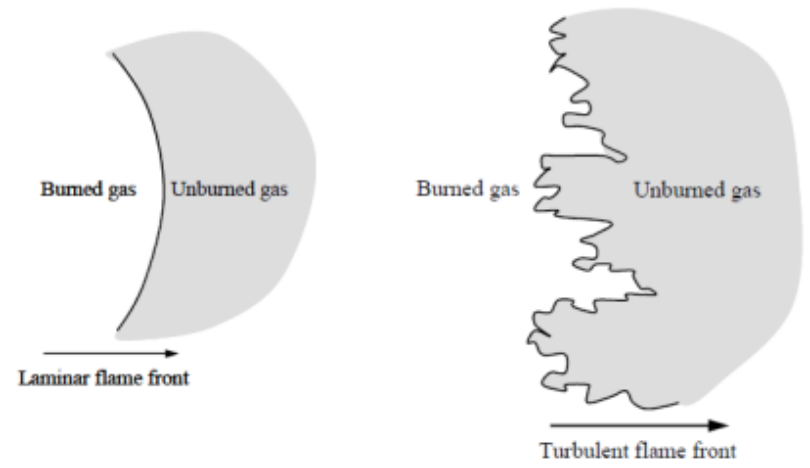

Fig. 10. Comparison between laminar and turbulent flame fronts during combustion in SI engine [51]

The increased flame front area raises heat transfer to nearby unburned gas. Since the temperature of the unburned gas elevates more quickly due to the increased heat transfer, it can reach ignition temperature and initiate combustion much faster than without a wrinkled flame front [51]. Hence, turbulence before ignition increases burn rate and reduce combustion duration.

Gulder [52] proposed empirical relationship for the turbulent premixed flame speed, $\mathrm{S}_{\mathrm{T}}$, as

$\frac{\mathrm{S}_{\mathrm{T}}}{\mathrm{S}_{\mathrm{L}}}=1+0.62\left(\frac{\mathrm{u}^{\prime}}{\mathrm{S}_{\mathrm{L}}}\right)^{1 / 2} \operatorname{Re}_{l}^{1 / 4}$

where $u^{\prime}$ is the turbulent fluctuating velocity 
and $\mathrm{S}_{\mathrm{L}}$ is the laminar flame speed. $\operatorname{Re}_{l}=\frac{\mathrm{u}^{\prime} l}{\mathrm{v}}$ with $l$ integral length scale being a measure of the size of large energy including the flow structures as shown in Fig. 11 and $v$ kinematic viscosity.

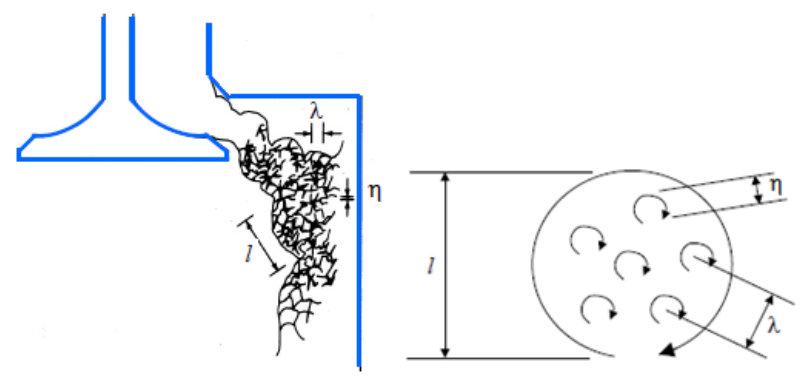

Fig. 11. Turbulent structure of the flow through intake valve

Under normal SI engine operating conditions, $\mathrm{S}_{\mathrm{T}}$ may be 5 to 10 times as big as $\mathrm{S}_{\mathrm{L}}$, which demonstrates the importance of enhancing $u^{\prime}$ in improving the burn rate [50].

The results of some experimental investigations $[9,20,53-58]$ illustrated that there was a strong correlation between increased charge motion and decreased the ignition delay (time period for $0-1 \%$ or $0-10 \%$ mass fraction burned (MFB)) and main combustion duration (time period for $10-90 \%$ MFB) in SI engines. For instance, Mikulec et al. [53] examined the effect of swirl varied from 0 to 2.8 on combustion in a pancake chamber SI engine. They concluded that changing the swirl ratio while holding the inducted kinetic energy constant reduced the ignition delay and the combustion duration by about $25 \%$ and $10 \%$ respectively, and significantly improved the combustion stability. Moreover, Kyriakides et al. [54] examined the impact of in-cylinder air motion produced by masked valves on SI engine performance. Accordingly, there was good correlation between $10-90 \%$ burn and the delay angles with turbulence intensity, and higher turbulence resulted in faster combustion. Porpatham et al. [55] also studied the influence of the masked valve generated swirl on the combustion characteristics and emissions in biogas fuelled SI engine. As a result, increase in swirl level brought about extension of the lean misfire limit of combustion and enhancement of brake thermal efficiency and power output at full throttle.

On the other hand, Arcoumanis et al. [56] proposed two different port shapes with and without metal sleeves to deflect the intake air flow to analyze the influence of tumble flow on the combustion and exhaust emission in a single-cylinder four-valve gasoline and compressed natural gas (CNG) SI engine. As a consequence, the sleeved port enhanced the flame propagation and reduced the convection of the flame far from the spark plug compared with non-sleeved port while the position of the flame appeared more variable from one cycle to the next as shown Fig. 12 (a) and (b).

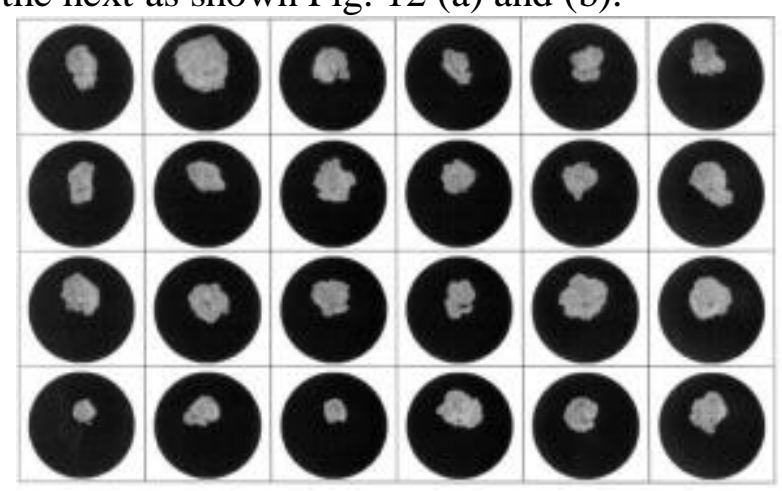

(a)

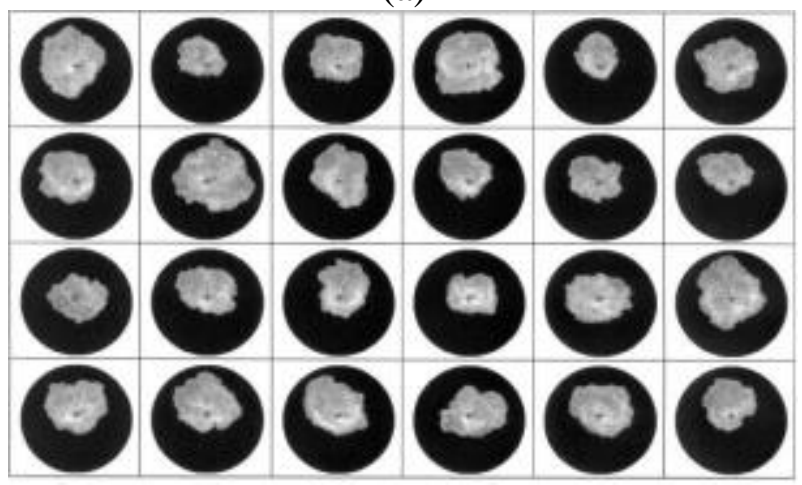

(b)

Fig. 12. The Flame propagation for two different intake port configurations over 24 cycles at $17^{\circ}$ after spark discharge under stoichiometric mixture conditions: (a) non-sleeved port (b) sleeved port [56].

However, Selamet et al. [57] used three intake runner blockages with $20 \%$ open area to produce swirl, tumble and swumble (combined swirl and tumble) in SI engines under part-load conditions and it was concluded the burning period was considerably shortened by tumble compared to swirl and swumble. In addition, Zhang et al. [58] emphasized that combination of the tumble generated intake valve in a SI engine with EGR (exhaust gas recirculation) contributed to a significant improvement in fuel economy and combustion duration at part loads. Besides, the influence of in-cylinder flow on airfuel mixture formation and the local excess air 
ratio, $\lambda$, distribution inside the combustion chamber of gasoline engines was concerned by researchers $[15,20,24,59,60]$. Urushihara et al. [20] examined the impacts of swirl and tumble flows generated swirl control valve on incylinder fuel vapor motion and the charge stratification in a lean burn SI engine. They concluded that a small tumble ratio was a necessary condition for axial mixture stratification but a large swirl ratio was not always effective in promoting stratification. Also, tumble motion enhanced the formation of a homogeneous mixture. Zheng et al. [59] investigated the effect of four piston shapes on GDI engine performance under catalyst heating mode by using CFD code. Simulation results showed that a piston with a flat top surface and pit was beneficial for improving the in-cylinder turbulence intensity, and helped in the formation of a combustible mixture around the spark plug at the time of ignition. The piston with a smoother top surface enhanced the turbulence kinetic energy at the time of ignition, thus accelerating combustion and increasing incylinder temperature and pressure. Zhou et al. [60] designed a port blocker on intake manifold to generate intake tumble and they then conducted the sweeping test of excess air coefficient ranging from 1 to 1.55 in a gasoline engine. They observed that intake tumble enhanced the lean burn limit without high the coefficient of cyclic variation.

In contrast to the S.I. engines, in C.I. engines only air (with small amount of residual gases) is compressed and the fuel as a finely atomized liquid is injected shortly before the piston reaches the TDC. The temperature of the fuel and the compressed air is greater than the ignition temperature of the fuel and the fuel begins to burn without any outside means of igniting it. The air movement within the combustion chamber of the diesel engine is one of the crucial factors in regulation of combustion process along with the fuel spray characteristics and the combustion chamber geometry.

Recently, various types of research related to piston bowl shapes have been conducted to improve fuel consumption and reduce harmful pollutants of CI engine [61-73]. For instance, Jaichandar et al. [63] studied the performance and emissions parameters in a biodiesel fueled
DI diesel engine for different combustion chambers such as Toroidal Combustion Chamber (TCC), Hemispherical Combustion Chamber (HCC) and Shallow depth Combustion Chamber (SCC). The test results showed that owing to TCC produced powerful squish caused improvement of air motion, brake thermal efficiency for TCC was higher than for the other two types of combustion chambers. Similarly, Li et al. [65] probed the impact of piston bowl geometry such as HCC, SCC and Omega Combustion Chamber (OCC) on combustion characteristics of a biodiesel fueled diesel engine at medium load conditions using the coupled KIVA4-CHEMKIN code. They concluded that at low engine speed, SCC had greater indicated work, cylinder pressure and heat release rate (HRR) peak in comparison with HCC and OCC whereas at medium and high engine speeds, OCC showed better performance than other bowl geometries because of producing strong squish in a short time. Further, Taghavifar et al. [66] analyzed the influence of modification in piston head shape in terms of bowl movement and the bowl size in four equal increments at constant compression ratio (CR) on the fluid flow, combustion, emission, and engine operation. They found that enhancing outward bowl movement provided better uniformity in air/fuel mixture resulted in higher peak pressure and HRR but combustion initiation delayed to late expansion period with lower work delivery acting negatively on engine performance and combustion heat production.

Consequently, augmentation of turbulence using different in cylinder charge motion generating methods increases combustion rate, in cylinder peak pressure and fuel efficiency. This leads to conversion of thermal to mechanical energy being more efficient with a shorter combustion period. Also, combustion stability can be improved with charge motion resulting in better engine performance particularly under part-load operating conditions.

\subsection{Exhaust emission}

The internal combustion engine produces exhaust emissions which are responsible for degradation in urban air quality. HC formation comes from fuel especially too lean and reach burn conditions primarily due to quenched 
regions in the combustion chamber, and $\mathrm{CO}$ is the incomplete oxidation product of the fuel carbon. On the other hand, $\mathrm{NO}_{\mathrm{x}}$ forms high temperature and the amount of oxygen in burned gases during the combustion stroke. One of the prominent techniques to control pollutant emission is optimizing combustion with enhanced in-cylinder turbulence especially lean operating conditions. Many researchers have been investigated this technique both experimentally and numerically $[18,20,25,55-$ 59, 61-64]. Udayakumar et al. [18] examined correlation between emission reduction and suction swirl generated inlet valve brazed with shrouds whose angles between $60^{\circ}$ and $120^{\circ}$ in $\mathrm{CI}$ engine and it was found that when the shroud angle elevated to $80^{\circ}$, the $\mathrm{CO}_{2}$ emission increased with a decrease in $\mathrm{CO}$ and $\mathrm{NOx}$ emissions. However, if shrouded angle was increased further, $\mathrm{CO}_{2}$ emission increased, but $\mathrm{CO}$ also increased because of incomplete burning of the fuel. They concluded that the shroud angle between $60^{\circ}$ and $80^{\circ}$ would be optimum and greater shroud angle only tended to increase in $\mathrm{CO}_{2}, \mathrm{CO}$ and $\mathrm{NOx}$ emissions. Similarly, Porpatham et al. [55] reported that the masked valve produced swirl decreased in HC level due to the improvement in combustion and increased in NO emission in biogas fueled SI engine under full throttle condition.

On the other hand, Urushihara et al [20] compared shrouded inlet valves with swirl/tumble motion generated swirl control valves located at the upstream end of the intake port to search mixture formation in a lean-burn SI engine and it was resulted that using the swirl-type swirl control valves produced a homogeneous mixture around the ignition timing and formed a low level of $\mathrm{NO}_{\mathrm{x}}$ emissions over a wide range of fuel injection timings except during the intake stroke compared with shrouded valve. Also, Bari et al. [25] used $25^{\circ}$ $45^{\circ}$ guide vane models to enhance performance and emissions in a biodiesel fueled CI engine and $35^{\circ}$ vane angle was determined to be the optimum vane angle since the lowest $\mathrm{NO}_{\mathrm{x}}$ and $\mathrm{HC}$ emissions as well as the highest engine efficiency and air/fuel ratio were obtained with this angle. Further, the tumble produced variable valve in intake manifold combined with EGR (exhaust gas recirculation) caused decrease of $\mathrm{NO}_{\mathrm{x}}$ and $\mathrm{CO}$ emissions and increase of $\mathrm{HC}$ emission slightly in a SI engine at part loads [58].

Selamet et al. [57] inquired three blockages of $20 \%$ open area produced organized intake charge motion and they showed that tumble and swirl reduced $\mathrm{CO}$ emissions, while increasing either $\mathrm{NO}_{\mathrm{x}}$ or $\mathrm{HC}$ for both operating conditions and swumble reduced $\mathrm{NO}_{\mathrm{x}}, \mathrm{HC}$, and $\mathrm{CO}$ emissions and swumble appeared to be most desirable for reduction of $\mathrm{HC}$ emission at partload conditions. Besides this, numerical simulation of the intake ports with different geometry was performed to study pollutant formation in DI diesel engines and it is concluded that the port configuration generating strong swirl flow resulted in enhanced soot oxidation and $\mathrm{NO}_{\mathrm{x}}$ formation [61].

Moreover, different combustion chamber geometries were considered to investigate the impact of the organized flow behavior on emissions [63- 67]. For example, Wei et al. [64] proposed a new swirl chamber combustion system of DI diesel engines with different swirl ratios (0.2-3.2) to develop the mixing quality and reduce exhaust emissions. The results showed that the lowest NO mass fraction was obtained at swirl ratio of 0.8 and the highest at swirl ratio of 2.7, whereas the lowest soot mass fraction was obtained at swirl ratio of 0.2 and the highest at swirl ratio of 3.2 and the emissions at swirl ratio of $0.8 \mathrm{had}$ a better performance in the new combustion system. Jaichandar et al. [63] observed that TCC significantly reduced particulates, carbon monoxide and unburnt hydrocarbons expense of slightly higher $\mathrm{NO}_{\mathrm{x}}$ compared to the other two chambers such as HCC and SCC. Likewise, Li et al. [65] reported that SCC generated relatively higher NO and lower CO compared to other two piston bowl shapes at low engine speed condition whereas OCC bowl geometry resulted in a high NO emission and a low $\mathrm{CO}$ concentration due to well mixed mixture at high engine speed condition. Besides this, various modifications in bowl radius and outer bowl with constant compression ratio were suggested to investigate soot and $\mathrm{NO}_{\mathrm{x}}$ emissions [66]. It was illustrated that increasing the outer wall diameter resulted in decreasing the soot concentration substantially and highest bowl radius had lowest soot mass fraction whereas $\mathrm{NO}_{\mathrm{x}}$ concentration increased with greater outer bowl diameter and 
reduced with smaller bowl radius.

As a result, with distinct in-cylinder flow generation methods, it is possible to reduce pollutant emissions such as $\mathrm{HC}, \mathrm{CO}$ and soot but $\mathrm{NO}_{\mathrm{x}}$ concentration generally increases because of high combustion temperature. Thus more accurate numerical methods along with experimental studies must be developed to decrease all harmful emissions produced by internal combustion engines to an optimal level.

\section{Conclusion}

This review study discloses that there is still not enough knowledge about formation and destruction of swirl, tumble and squish flow enhancing turbulence intensity which controls cycle-to-cycle variation, combustion efficiency and exhaust emission in internal combustion engines. Swirl and tumble flows are complementary each other and their combined effect offers to most promise especially for stable lean engine operation. On the other hand squish flow is generally inadequate to augment turbulence level by itself and excessive squish may lead to some problems such as engine knock and increase of unburnt charge. Many researchers have inspected only effect of incylinder flows on turbulence characteristics. But full picture of engine performance is necessary to examine correlation swirl, tumble and squish flows with combustion and exhaust emission parameters. The results of various experiments related to organized intake flow, combustion and residual pollutant showed that an increase in turbulence intensity led to obtaining more homogenous air-fuel mixture and reducing of combustion duration, cyclic fluctuation and air pollution emissions. Since experimental methods are more expensive, they must be supported with computational techniques such as multidimensional CFD modeling which provides the required data for analysis of in cylinder motion, some of which cannot be measured in experimental studies. To examine interaction between air and/or air-fuel flow, moving geometries, fuel injection, and combustion, full cycle CFD simulation must be investigated. In this way, after solution of the unsteady equations for flow, turbulence, energy and chemistry, useful information is extracted from very large data sets. For example, ANSYS Workbench ICE System provides an integrated environment with powerful tools for geometry, meshing, CFD solvers and post processing on a common platform. In order to obtain optimum design of internal combustion engines, similar computational software including analysis of geometry such as ports, valves, cylinder heads and pistons, in-cylinder flow, turbulence intensity, combustion and emission phenomena must be improved.

\section{References}

1. Lumley, J. L. (1999). Engines, Cambridge University Press.

2. Pulkrabek, W-W. (1998). Engineering fundamentals of the internal combustion engine, Prentice-Hall, Upper Saddle River, New Jersey. 3. Horrocks, G. (2001). A numerical study of a rotary valve internal combustion engine, $\mathrm{PhD}$ Thesis, Faculty of Engineering, The University of Technology, Sydney.

4. Taylor, C. F. (1968). The internal combustion engine in theory and practice, volume 2. Massachusetts Institute of Technology Press, Massachusetts.

5. Wigley, G. and Hawkins, M. G. (1978). Three dimensional velocity measurements by laser anemometry in a diesel engine cylinder under steady state inlet flow conditions, SAE Paper 780060.

6. Pettiffer, H. F. (1982). Interaction of port design and injection rate for a D.I. diesel, SAE Paper 820358.

7. Arcoumanis, C., Hu, Z., Vafidis, C., and Whitelaw, J. H. (1990). Tumbling motion-A mechanism for turbulence enhancement in spark-ignition engines, SAE Paper 900060.

8. Omori, S., Iwachido, K., Motomochi, M., and Hirako, O. (1991). Effect of intake port flow pattern on the in-cyliner tumbling air flow in mlti-valve SI engines, SAE Paper 910477.

9. Hadded, O., and Denbratt, I. (1991). Turbulence characteristics of tumbling air motion in 4-valve SI engines and their correlation with combustion parameters, SAE Paper 910478.

10. Kang, K-Y., Oh, S-M., Lee, J-W., Lee, K-H., and Bae, C-S. (1997). The effects of tumble flow on lean burn characteristics in a 4valve SI engine, SAE Paper 970791.

11. Li, Y. F., Li, L. L., Xu, J. F., Gong, X. H., Liu, S. L., and Xu, S. D. (2000). Effects of combination and orientation of intake ports on 
swirl motion in four-valve DI diesel engines, SAE Paper 2000-01-1823.

12. Rajput, R. K. (2007). Internal combustion engines, New Delhi: Laxmi Publications Ltd.

13. Nishiwaki, K. (1985). Prediction of three-dimensional fluid motions during intake process and swirl ratios in four-cycle engines, International Symposium on Diagnosistics and Modeling of Combustion in Reciprocating Engines, Tokyo, September.

14. Arcoumanis, C., and Tanabe, S. (1989). Swirl generation by helical ports, SAE Paper 890790.

15. Hill, P. G., and Zhang, D. (1994). The effect of swirl and tumble on combustion in spark ignition engines, Prog. Energy Combust. Sci., 20:373-429.

16. Heywood, J. B. (1988). Internal combustion engine fundamentals, McGrawHill, New York.

17. Li, Y., Zhao, H., Peng, Z., and Ladommatos N. (2002). Tumbling flow analysis in a four-valve spark ignition engine using particle image velocimetry, Int. J. Engine Res., 3(3): 139-155.

18. Udayakumar, R., Arasu, P. V., and Sriram, S. (2003). Experimental investigation on emission control in C.I. engines using shrouded inlet valve, SAE Paper 2003-01-0350. 19. Khalighi, B., Tahry, S. H. E., Haworth, D. C., and Huebler, M. S. (1995). Computation and measurement of flow and combustion in a four- valve engine with intake variations, SAE Paper 950287.

20. Urushihara, T., Nakada, T., Kakuhou, A., and Takagi, Y. (1996). Effects of swirl/tumble motion on in-cylinder mixture formation in a lean-burn engine, SAE Paper 961994.

21. Arcoumanis, C., Hu, Z., and Whitelaw, J. H. (1992). Steady flow characterization of tumble generating four valve cylinder heads, Proc. Instn. Mech. Engrs., 207: 203-210.

22. Floch, A., Frank, J.V., and Ahmed, A. (1995). Comparison of effects of intakegenerated swirl and tumble on turbulence characteristics in a 4-valve engine, SAE Paper 952457.

23. Pipitone, E., and Mancuso, U. (2005). An experimental investigation of two different methods for swirl induction in a multivalve engine, International Journal of Engine Research, 6(2): 159-170.

24. Lee, K., Bae, C., Kang K . (2007). The effects of tumble and swirl flows on flame propagation in a four-valve S.I. engine, Applied Thermal Engineering, 27: 2122-2130.

25. Bari S., and Saad I. (2015). Performance and emissions of a compression ignition (CI) engine run with biodiesel using guide vanes at varied vane angles, Fuel, 143: 217-228.

26. Payri, F., Benajes, J., Margot, X., and Gil, A. (2004). CFD modeling of the in-cylinder flow in direct-injection Diesel engines, Computers \& Fluids, 33: 995-1021.

27. Gunabalan, A., and Ramprabhu, R. (2009). Effect of piston bowl geometry on flow, combustion and emission in DI engines-a CFD approach, International Journal of Applied Engineering Research, 4(11): 2181-2188.

28. Raj A. R. G. S., Mallikarjuna J. M., and Ganesan V. (2013.). Energy efficient piston configuration for effective air motion - A CFD study, Applied Energy, 102: 347-354.

29. Harshavardhan, B., Mallikarjuna J.M. (2015). Effect of piston shape on in-cylinder flows and air-fuel interaction in a direct injection spark ignition engine - A CFD analysis, Energy, 81: 361-372.

30. Arcoumanis, C., Bicen, A. F., and Whitelaw, J. H. (1981). Measurements in a motored four-stroke reciprocating model engine, Fluid Mech. of Combustion System, presented at the Fluids Eng. Conf., ASME, Boulder, Colorado, June 22-23.

31. Liou, T. M., and Santavica, D. A. (1983). Cycle resolved turbulence measurements in a ported engine with and without swirl, SAE Paper 830419.

32. Hamamoto, Y., Tomita, E., Tanaka, Y., and Katayama, T. (1985). The effect of swirl on spark ignition engine combustion, International Symposium on Diagnostics and Modeling of Combustion in Reciprocating Engines, Tokyo, September.

33. Hall, M. J., and Bracco, F. V. (1987). A study of velocities and turbulence intensities measured in firing and motored engines, SAE Paper 870453.

34. Kang, K.Y., and Reitz, R.D. (1999). The effect of intake valve alignment on swirl generation in a di diesel engine, International 
Journal of Experimental Thermal and Fluid Science, 20: 94-103.

35. Yun J-E. (2002). New evaluation indices for bulk motion of in-cylinder flow through intake port system in cylinder head, Journal of Automobile Engineering, 216: 513-521.

36. Choi G. H., Kim S. H., Kwon T. Y., Yun J. H., Chung Y. J., Ha C. U., Lee J. S., and Han S. B. (2006). A numerical study of the effects of swirl chamber passage hole geometry on the flow characteristics of a swirl chamber type diesel engine, Journal of Automobile Engineering, 220: 459-470.

37. Bottone F., Kronenburg A., Gosman D., and Marquis A. (2012). Large eddy simulation of diesel engine in-cylinder flow, Flow, Turbulence and Combustion, 88: 233-253.

38. Achuth M., and Metha P.S. (2001). Predictions of tumble and turbulence in fourvalve pentroof spark ignition engines, International Journal of Engine Research, 2: 209-227.

39. Kang, K-Y., and Baek, J-H. (1998). Turbulence characteristics of tumble flow in a four-valve engine, Experimental Thermal and Fluid Science 18: 231-243.

40. Jeng, Y.L., Chen, R.C., and Chang, C.H. (1999). Studies of tumbling motion generated during intake in a bowl-in-piston engine. Journal of Marine Science and Technology, 7(1): 52-64.

41. Urushihara, T., Murayama, T., Takagi, Y., and Lee, K. H. (1995). Turbulence and cycle-by-cycle variation of mean velocity generated by swirl and tumble flow and their effects on combustion, SAE Paper 950813.

42. Lee, K.H., and Lee, C.S. (2003). Effects of tumble and swirl flows on turbulence scale near top dead centre in a four-valve spark ignition engine, Journal of Automobile Engineering, 217: 607-615.

43. Micklow, G.J., and Gong W.D. (2007). Intake and in cylinder flow field modeling of a four valve diesel engine, Journal of Automobile Engineering, 221:1425-1440.

44. Ramajo D., Zanotti A, and Nigro N. (2011). In-cylinder flow control in a four-valve spark ignition engine: numerical and experimental steady rig tests, Journal of Automobile Engineering, 225: 813-828.

45. Towers J. M., and Hoekstra R. L. (1998). Engine knock, a renewed concern in motorsports - a literature review, SAE Paper 983026.

46. Arcoumanis, C., and Whitelaw, J. H. (1987). Fluid mechanics of internal combustion engines - a review, Proc. Instn. Mech. Engrs, 201: 57-74.

47. Rutland C.J., Ayoub N., Z., Han, Hampson G., Kong S.-C., Mather D., Montgomery D., Musculus M., Patterson M., Pierpont D., Ricart L., Stephenson P., and Reitz R.D. (1995). Diesel engine model development and experiments, SAE Paper 951200.

48. Zolver M., Griard C., and Henriot S. (1997). 3d modeling applied to the development of a DI diesel engine: effect of piston bowl shape, SAE Paper 971599.

49. Auriemma M., Corcione F. E. , Macchioni R., and Valentino G. (1998). Interpretation of air motion in reentrant bowl inpiston engine by estimating reynolds stresses, 980482 SAE Paper.

50. Huang R.F., Yang H.S., and Yeh C.-N. (2008). In-cylinder flows of a motored fourstroke engine with flat-crown and slightly concave-crown pistons, Exper. Therm. Fluid Sci., 32: 1156-1167.

51. He, Y. (2007). Effect of intake primary runner blockages on combustion characteristics and emissions in spark ignition engines, $\mathrm{PhD}$ Thesis, University of Ohio, USA.

52. Gulder, O. L. (1991). Turbulent premixed combustion modeling using fractal geometry, Proceedings of The Combustion Institute, 23: 835-842.

53. Mikulec, A., Kent, J. C., and Tabaczynski, R. J. (1988). The effect of swirl on combustion in a pancake chamber spark ignition engine: the case of constant kinetic energy, SAE Paper 880200.

54. Kyriakides, S. C., and Glover, A. R. (1989). A study of the correlation between incylinder air motion and combustion in gasoline engines, Journal of Automobile Engineering, 203: 185-292.

55. Porpatham E., Ramesh A., and Nagalingam B. (2013). Effect of swirl on the performance and combustion of a biogas fuelled spark ignition engine, Energy Conversion and Management, 76: 463-471.

56. Arcoumanis, C., Godwin, S.N., and Kim, J.W. (1998). Effect of tumble strength on 
exhaust emissions in a single cylinder 4-valve S.I engine, SAE Paper 981044.

57. Selamet, A., Rupai, S., and He, Y. (2004). An experimental study on the effect of intake primary runner blockages on combustion and emissions in SI engines under part-load conditions, SAE Paper 2004-01-2973.

58. Zhang Z., Zhang H., Wang T., and Jia M (2014). Effects of tumble combined with EGR (exhaust gas recirculation) on the combustion and emissions in a spark ignition engine at part loads, Energy, 65: 18:24

59. Zheng, Z. L., Liu, C. T., Tian, X. F. and Zhang, X. Y. (2015). Numerical study of the effect of piston top contour on GDI engine performance under catalyst heating mode. Fuel, 157: 64-72.

60. Zhou F., Fu J., Ke W., Liu J., Yuan Z. and Luo B. Effects of lean combustion coupling with intake tumble on economy and emission performance of gasoline engine. Energy, 133: 366-379.

61. Stephenson, P. W., Claybaker, P. J., and Rutland, C. T. (1996). Modeling the effects of intake generated turbulence and resolved flow structures on combustion in DI diesel engines, SAE Paper 960634.

62. Rakopoulos C.D., Kosmadakis G.M., and Pariotis E.G. (2010). Investigation of piston bowl geometry and speed effects in a motored HSDI diesel engine using a CFD against a quasidimensional model, Energy Conversion and Management, 51: 470-484.

63. Jaichandar S, and Annamalai K. (2012). Effects of open combustion chamber geometries on the performance of pongamia biodiesel in a DI diesel engine, Fuel, 98: 272-279.

64. Wei S., Wang F., Leng X., Liu X., and Ji K. (2013). Numerical analysis on the effect of swirl ratios on swirl chamber combustion system of DI diesel engines, Energy Conversion and Management, 75:184-90.

65. Li J., Yang W.M., An H., Maghbouli A., and Chou S.K. (2014). Effects of piston bowl geometry on combustion and emission characteristics of biodiesel fueled diesel engines, Fuel, 120: 66-73.

66. Taghavifar H., Khalilarya S., and Jafarmadar S. (2014). Engine structure modifications effect on the flow behavior, combustion, and performance characteristics of
DI diesel engine, Energy Conversion and Management, 85: 20-32.

67. Prabhakaran P., Ramesh P., Saravanan C.G., Loganathan M. and Gunasekaran E. J. (2016). Experimental and numerical investigation of swirl enhancing grooves on the flow and combustion characteristics of a DI diesel engine, Energy, 115: 1234-1245.

68. Ravi K., Porpatham E. (2017). Effect of piston geometry on performance and emission characteristics of an LPG fuelled lean burn SI engine at full throttle condition, Applied Thermal Engineering 110: 1051-1060.

69. Yan B., Tong L., Wang H., Zheng Z., Qin Y. and Yao M. (2017). Experimental and numerical investigation of the effects of combustion chamber reentrant level on combustion characteristics and thermal efficiency of stoichiometric operation natural gas engine with EGR, Applied Thermal Engineering, 123: 1473-1483.

70. Calik A. T.,Taskiran O. O., Mehdiyev R. (2018). Numerical investigation of twin swirl application in diesel engine combustion, Fuel, 224: 101-110.

71. Hamid M.F., Idroas M. Y., Sa'ad S., Bahri A.J.S., Sharzali C.M., Abdullah M.K and Zainal Z.A. (2018). Numerical investigation of in-cylinder air flow characteristic improvement for emulsified biofuel (EB) application, Renewable Energy, 127: 84-93.

72. Baratta M., Misul D., Viglione L. and Xu J. (2019). Combustion chamber design for a high-performance natural gas engine: CFD modeling and experimental investigation, Energy Conversion and Management, 192: 221231.

73. Karthickeyan V. (2019). Effect of combustion chamber bowl geometry modification on engine performance, combustion and emission characteristics of biodiesel fuelled diesel engine with its energy and exergy analysis, Energy, 176: 830-852. 